Review

https://doi.org/10.1631/jzus.B2000808
Check for updates

\title{
Toll-like receptor 3 (TLR3) regulation mechanisms and roles in antiviral innate immune responses
}

\author{
Yujuan CHEN ${ }^{1,2}$, Junhong LIN $^{1,2}$, Yao ZHAO ${ }^{1,2}$, Xianping MA ${ }^{1,2}$, Huashan $\mathrm{YI}^{1,2,3 凶}$ \\ ${ }^{I}$ College of Veterinary Medicine, Southwest University, Chongqing 402460, China \\ ${ }^{2}$ Chongqing Veterinary Science Engineering Research Center, Chongqing 402460, China \\ ${ }^{3}$ Immunology Research Center, Medical Research Institute, Southwest University, Chongqing 402460, China
}

\begin{abstract}
Toll-like receptor 3 (TLR3) is a member of the TLR family, mediating the transcriptional induction of type I interferons (IFNs), proinflammatory cytokines, and chemokines, thereby collectively establishing an antiviral host response. Studies have shown that unlike other TLR family members, TLR3 is the only RNA sensor that is utterly dependent on the Tollinterleukin-1 receptor (TIR)-domain-containing adaptor-inducing IFN- $\beta$ (TRIF). However, the details of how the TLR3-TRIF signaling pathway works in an antiviral response and how it is regulated are unclear. In this review, we focus on recent advances in understanding the antiviral mechanism of the TRIF pathway and describe the essential characteristics of TLR3 and its antiviral effects. Advancing our understanding of TLR3 may contribute to disease diagnosis and could foster the development of novel treatments for viral diseases.
\end{abstract}

Key words: Toll-like receptor 3 (TLR3); Toll-interleukin-1 receptor (TIR)-domain-containing adaptor-inducing interferon- $\beta$ (TRIF); Innate immune; Antiviral response

\section{Introduction}

Antiviral innate immune and inflammatory responses are the body's front lines of defense against viral infection (Yang and Shu, 2020). Rapid and effective recognition of microbial infection or danger signals from within the cell by the innate immune system is a premise for eliciting host responses to repulse the threats (Liu and Gack, 2020). The innate immunity of animals depends on pattern-recognition receptors (PRRs) that specifically recognize pathogenassociated molecular patterns (PAMPs) and then activate a signaling cascade triggering the type I interferon (IFN)- and interleukin-1 (IL-1)-mediated proinflammatory responses (Rai, 2020). The virus-perceiving PRRs mainly include Toll-like receptors (TLRs), retinoic acid-inducible gene-I (RIG-I)-like receptors (RLRs), and DNA sensors, such as cyclic guanosine

$\triangle$ Huashan YI, dyxyihuashan@swu.edu.cn

(D) Huashan YI, https://orcid.org/0000-0001-9205-2155

Received Dec. 22, 2020; Revision accepted Apr. 9, 2021; Crosschecked July 21, 2021

(C) Zhejiang University Press 2021 mono-phosphate-adenosine monophosphate (GMPAMP) synthase (cGAS), IFN- $\gamma$-inducible protein-16 (IFI16), and the recently identified heterogeneous nuclear ribonucleoprotein A2/B1 (hnRNPA2B1) (Unterholzner et al., 2010; Sun et al., 2013; Wang L et al., 2019). TLRs are expressed mostly on the membranes of endosomes and lysosomes or on the surfaces of macrophages and dendritic cells (DCs), among other cell types, and are used to detect a wide range of microbial cell-wall-associated PAMPs and endosomal nucleic acids (Blasius and Beutler, 2010; Liu and Gack, 2020). RLRs are representative of cytoplasmic PRRs, which recognize both viral and host RNAs, even in sterile conditions via different mechanisms (Loo and Gale, 2011; Rehwinkel and Gack, 2020). Most RNA sensors reside in the endosome and cytoplasm, while PRR-mediated RNA sensing was recently shown also to occur in the nucleus and mitochondrion (Liu et al., 2018; Cao LL et al., 2019; Wang Y et al., 2019). In addition to PAMPs, PRRs can recognize tissue damage-associated molecular patterns (DAMPs) and play an essential role in promoting tissue repair and regeneration. However, they also cause numerous inflammatory diseases, such as metabolic disorders 
and autoimmune diseases (Mortaz et al., 2017; Gong et al., 2020).

TLRs were the first PRRs to be identified and are the best characterized (Kawasaki and Kawai, 2014). The TLR family consists of 10 members (TLR1-TLR10) in humans and 12 members (TLR1TLR9, TLR11-TLR13) in mice (Takeda and Akira, 2015). Each TLR is composed of an ectodomain (ECD) that mediates PAMP recognition, a transmembrane domain, and a cytoplasmic Toll-IL-1 receptor (TIR) domain responsible for downstream signaling (Kang and Lee, 2011). The signaling pathway of TLRs mainly includes the myeloid differentiation primary response protein 88 (Myd88)-dependent TLR signaling pathway and the TIR-domain-containing adaptor-inducing IFN- $\beta$ (TRIF)-dependent TLR signaling pathway. The members of the TLR family selectively use adaptor proteins, including the TRIF (also called TIR-containing adapter molecule 1 (TICAM-1)), MyD88, transverse rectus abdominis musculocutaneous (TRAM) flap, and TIR-containing adaptor protein (TIRAP), to activate overlapping but distinct signaling pathways. These pathways initiate the transcriptional induction of mediators such as type I IFN and chemokines (Kawasaki and Kawai, 2014). TLR1, TLR2, and TLR5-TLR9 work via the Myd88-dependent TLR signaling pathway, TLR3 works via the TRIF-dependent TLR signaling pathway, and TLR4 triggers both pathways (Takeda and Akira, 2015).

TLR3 recognizes double-stranded RNA (dsRNA), which is a viral replication intermediate, and initiates downstream signal transduction, thereby up-regulating the expression of IFN- $\alpha / \beta$ and inducing antiviral protein (AVP) synthesis activity (Matsumoto et al., 2011). DEAD (Asp-Glu-Ala-Asp) box polypeptide 1 (DDX1), DDX21, and DHX36, the members of the DExD/ H-box helicase cytosolic sensors of dsRNA, share with TLR3, the TRIF for downstream type I IFN signaling (Zhang et al., 2011). TLR3 is the only receptor in the TLR family that depends entirely on the TRIF to induce IFN- $\beta$ production (Yang and Shu, 2020). According to the different downstream products activated by TRIF, the TLR3-mediated signaling pathway can be divided into the TRIF-dependent nuclear transcription factor- $\mathrm{kB}(\mathrm{NF}-\mathrm{\kappa B})$ pathway and TRIFdependent IFN-regulatory factor 3/7 (IRF3/7) pathway (Matsumoto et al., 2011). Once activated on the plasmalemma by exogenous dsRNA, TRIF interacts with tumor necrosis factor (TNF) receptor-associated factor 3 (TRAF3) and TRAF6 to trigger a series of cascade reactions. The mechanisms and negative regulation of TRIF are currently areas of active research that we emphasize in this review.

\section{Characteristics and recognition of TLR3}

\subsection{Basic characteristics of TLR3}

TLR3 is widely expressed in neurocytes, immune cells, fibroblasts, and various epithelial cells (Kulka et al., 2004; Town et al., 2006; Fang et al., 2013; Bugge et al., 2017; Chen et al., 2019). Among immune cells, only myeloid DCs, macrophages, and mast cells (MCs) express TLR3. TLR3 localizes both at the cell surface and in endosomes in MCs and macrophages, but only in endosomes in myeloid DCs (Matsumoto et al., 2003, 2011; Agier et al., 2016). DCs are one of the most important immune cells that produce IFNs, including type I IFNs ( $\alpha$ and $\beta$ ), which are associated with viral clearance (Matsumoto et al., 2003). TLR3 works in antigen-presenting DCs to induce lymphocytemediated antigen-specific immune responses (Matsumoto et al., 2020; Soto et al., 2020). MCs have been reported to act as sentinel cells of innate immunity, extensively engaged in infection control and clearance (Piliponsky and Romani, 2018; Marshall et al., 2019). MCs express TLR3 molecules and other proteins associated with the cellular antiviral response, like IRF3, types I and II IFN receptors, and major histocompatibility complex (MHC) I (Witczak et al., 2020).

TLR3 consists of an ECD, a cytoplasmic TIR domain, a transmembrane domain, and two flanking regions, known as the leucine-rich repeat (LRR) C-terminal (LRR-CT) and N-terminal (LRR-NT) regions (Choe et al., 2005). The TLR3-transmembrane domain and ECD structures have been resolved through X-ray crystallography; nevertheless, the structure of a membrane-solvated full-length receptor remains inaccessible (Liu et al., 2008; Mineev et al., 2014). Molecular dynamics simulation has demonstrated that the stabilization of the TLR3-TIR dimerization interface relies on reciprocal contact between the $\alpha \mathrm{C}$ and $\alpha \mathrm{D}$ helices of one subunit and the $\alpha \mathrm{C}$ helix and BB loop of the other (Patra et al., 2020). As a 
highly conserved region in the TIR domain, the BB loop is essential for mediating interactions among TIR domain-containing proteins (Singh et al., 2014). In the TLR3 A795P homodimer, the individual subunits are tilted slightly toward each other, which influences the orientation of the BB loops on the homodimer and, in turn, the binding of the TIR domain of TRIF to the homodimer (Mahita and Sowdhamini, 2018).

\subsection{Recognition of dsRNA by TLR3}

\subsubsection{Activation of TLR3}

The common ligands of TLR3 exist on poly(I:C), dsRNA viruses (e.g., rotavirus (RV), respiratory syncytial virus (RSV), murine cytomegalovirus (MCMV)), and single-stranded RNA (ssRNA) virus (e.g., West Nile virus (WNV)) (Alexopoulou et al., 2001; Topping and Kelly, 2019; Uehata and Takeuchi, 2020). A recent report showed that endothelial TLR3 could also detect extracellular dsRNA that is secreted from highly metastatic tumors (Tavora et al., 2020). TLR3 exists as a monomer and a membrane receptor in resting cells, and dimerizes only when bound to ligands via its ECD (Botos et al., 2009). The TLR3 ECD is formed by 23 LRRs, and the crystal structure resembles a sizeable horseshoe-shaped solenoid (Botos et al., 2009). Binding of the ECD domain of TLR3 to dsRNA requires an acidic environment (Leonard et al., 2008). As TLR3 functions mainly in the endosomes, several mechanisms have been suggested to account for delivery of extracellular TLR3-activatory dsRNA molecules into endosomes (Tabeta et al., 2006; Barton and Kagan, 2009; Pelka et al., 2018). Mainstream theories include the uptake of apoptotic bodies from infected cells (Salio and Cerundolo, 2005), clathrindependent endocytosis (Itoh et al., 2008; Watanabe et al., 2011), formation of dsRNA complexes with antimicrobial peptide LL-37 (Singh et al., 2013; Takahashi et al., 2018), and autophagic uptake of dsRNA from the cytosol and trafficking to endosomes with inhibited lysosomal degradation (Søreng et al., 2018; Galluzzi and Green, 2019; Hase et al., 2020). Whether TLR3 can be activated from the cell surface is still unknown.

\subsubsection{Structural basis of TLR3}

When TLR3 associates with dsRNA, a dsRNATLR3 signaling complex composed of one dsRNA and two TLR3 molecules is formed (Liu et al., 2008; Peisley and Hur, 2013). The molecular structure of a signaling unit (SU) shows that dsRNA ligands bind two regions, one at the C-terminus (LRR19-LRR21) and the other near the N-terminus (LRR-NT and LRR1LRR3) (Gao et al., 2015). TLR3 binds with ligands exclusively via surface contacts (mainly hydrogen bonding and electrostatic interactions), while the protein-protein interactions occur only at the LRRCT in the TLR3-dsRNA complex (Gao et al., 2015). Mutational analysis of human TLR3 has revealed that His39, His60, and His108 residues at the N-terminus, and His539 and Asn541 residues at the C-terminus, interact with dsRNA. The C-terminal dimerization site is critical for dsRNA binding and TLR3 signaling (Liu et al., 2008; Wang Y et al., 2010). Gao et al. (2015) found a weak dimer interface at the TLR3 ECD C-terminal site, which is required for effective dsRNA binding, and Pro680 is crucial for maintaining the dimer interface.

Studies have shown that, like TLR9, once within endosomes, TLR3 is cleaved by several cathepsins within its ECD because the full-length (non-cleaved) proteins are unable to form contacts with one another essential for receptor dimerization (Ewald et al., 2011; Fitzgerald and Kagan, 2020). The cleaved fragments remain associated with each other, and both are important for the inflammatory activity of TLR9/3 (Fitzgerald and Kagan, 2020). However, more research is required to clarify the type of cathepsins required for cleaving TLR3 and how TLR3 is proteolytically processed. Furthermore, Luo et al. (2012) demonstrated that lateral SU clustering is necessary for productive TLR3 signaling. Three neutralizing Fab fragments (Fab15, Fab12, and Fab1068) of three antibodies prevent the lateral clustering of SUs along the length of the dsRNA ligand, resulting in antagonism towards TLR3 signaling. This indicates that lateral clustering of SUs is necessary for TLR3 signal transduction. The structure of the TLR3-dsRNA signaling complex is shown in Fig. 1.

\subsubsection{Structural basis of dsRNA}

The minor groove, which contains degenerate sequence information, and the phosphate backbone are the main determinants of dsRNA binding to receptors (Doyle and Jantsch, 2002; Leonard et al., 2008). The major groove, which contains sequence-specific 


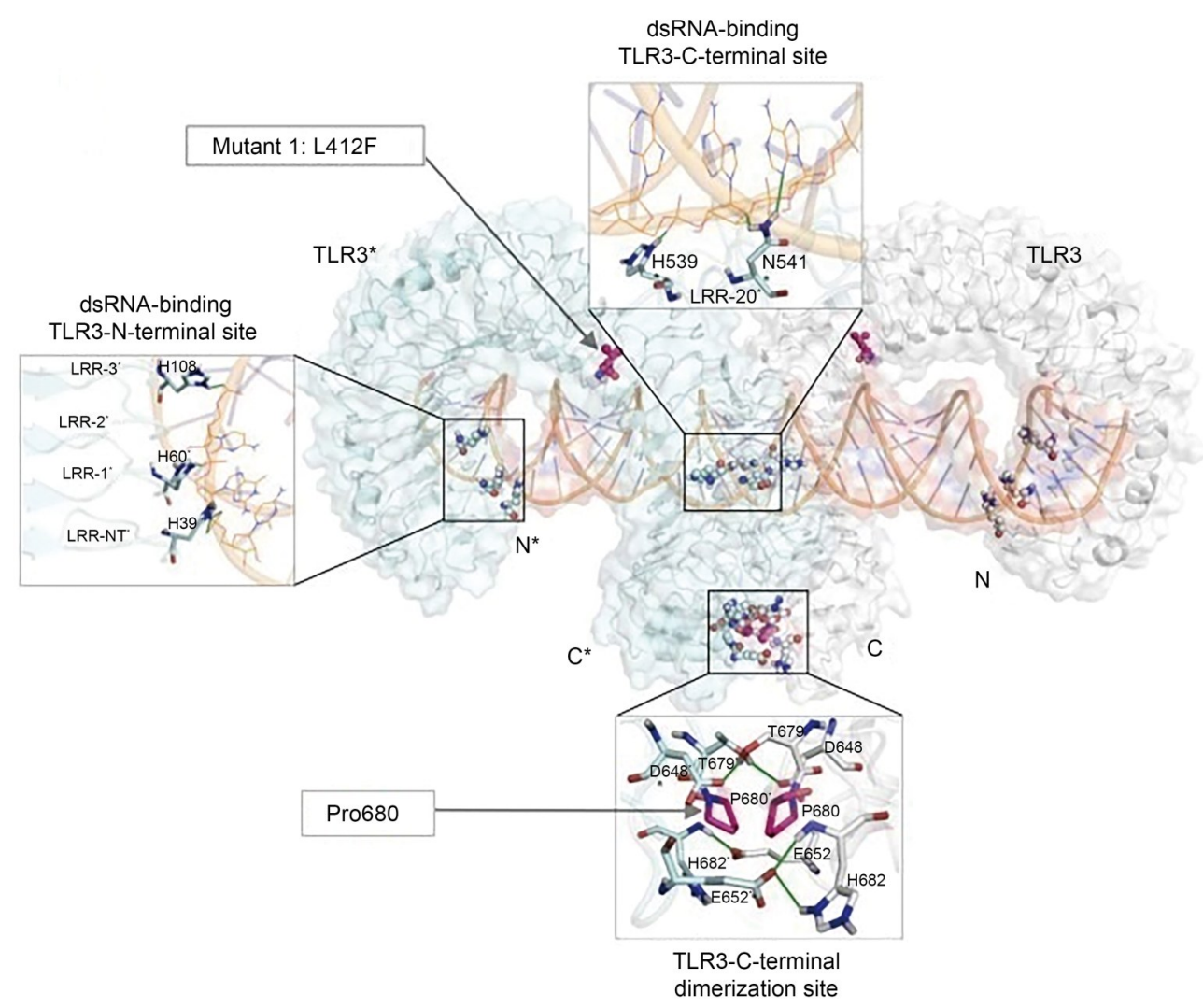

Fig. 1 Structure of the human TLR3-dsRNA complex and three crucial interaction sites (Gosu et al., 2019). Individual chains of the TLR3 complex are shown in white (TLR3) and cyan (TLR3 ${ }^{*}$ ). dsRNA, hydrogen bonds, and mutant residues are shown in orange, green, and magenta, respectively. For clarity, only the TLR3 ${ }^{*} \mathrm{~N}$ - and C-terminal interaction sites of dsRNA (46 bp) binding are shown. TLR: Toll-like receptor; dsRNA: double-stranded RNA.

information, is a common site of double-stranded DNA (dsDNA)-protein interaction (Pabo and Sauer, 1984). Since dsRNA is also found in many cellular RNAs, three mechanisms have been proposed to be responsible for discrimination between viral and cellular dsRNAs by TLR3. First, the endosomal location of the TLR3 ECD restricts access of cellular dsRNAs to TLR3 (Sioud, 2006). Second, the presence of modified nucleotides such as $N$-methyladenosine and 2-thiouridine provides an additional physicochemical specificity for TLR3 to discriminate between self and non-self dsRNAs (Karikó et al., 2005). Third, TLR3 requires dsRNA to be longer than $40 \mathrm{bp}$ for robust stimulation, which helps avoid inappropriate recognition of some cellular small interfering RNAs (siRNAs), microRNAs (miRNAs), or ssRNAs with short hairpin structures (Leonard et al., 2008). Other studies, however, showed that exogenously introduced 21-bp siRNA can also stimulate TLR3, suggesting that a high dose of RNA may compensate for the low-affinity interaction with short dsRNA (Karikó et al., 2004; Kleinman et al., 2008). This evidence suggests that dsRNA length is not an absolute criterion used by TLR3 for self and non-self discrimination, but rather a relative condition that can be scaled by the abundance of RNA and receptors in the cell (Peisley and Hur, 2013). How shorter dsRNA ligands (21$39 \mathrm{bp)}$ activate TLR3 signaling remains to be determined. It is also unclear how dsRNA ligands longer than $90 \mathrm{bp}$ are sensed, which may induce higher-order oligomerization of the receptor (Luo et al., 2012).

\subsubsection{Relevant proteins}

TLR3 presents a K63-linked poly-ubiquitination at K831 by the E3 ubiquitin ligase tripartite motifcontaining protein 3 (TRIM3), which is located mainly in the Golgi apparatus ( $\mathrm{Li}$ et al., 2020). Then, the polyubiquitinated TLR3 is distributed to endolysosomes to sense viral dsRNA and trigger an antiviral response. The cytoplasmic TIR domain of TLR3 is 
tyrosine-phosphorylated upon ligand binding (Sarkar et al., 2003). Bruton's tyrosine kinase (BTK) was reported to phosphorylate the cytoplasmic domain of TLR3, particularly the critical Tyr759 residue (Lee et al., 2012).

Cluster of differentiation (CD14), a class-A scavenger receptor, and clathrin-mediated endocytic pathways participate in cellular uptake of extracellular dsRNA (Lee et al., 2006; Itoh et al., 2008; Limmon et al., 2008). However, a recent report indicated that human CD14 acts as a co-receptor only to human TLR9, not to TLR3, TLR7, or TLR8 (Weber et al., 2012). Mex3 RNA-binding family member B (Mex3B), an RNA-binding protein, is reportedly involved in the process of presenting endocytosed dsRNA to TLR3 in intracellular compartments (Yang et al., 2016; Zhu et al., 2016). Mex3B acts as a co-receptor of TLR3 in response to dsRNA, promoting dsRNA binding with endosomal TLR3 and proteolytic processing of TLR3 (Yang et al., 2016; Zhu et al., 2016). The zincfinger FYVE domain-containing protein ZFYVE1 was revealed to promote the binding of TLR3 to poly(I:C) by associating with the ECD of TLR3 via its FYVE domain (Zhong et al., 2020). Ectopically expressed ZFYVE1 binds to the poly(I: C), and thus enhances the binding of TLR3 to poly(I: C) (Yamashita et al., 2012; Zhong et al., 2020). The relationship between Mex3B and ZFYVE1 in regulating the TLR3-mediated response is unclear. Luo et al. (2020) demonstrated that the Sh2 domain-containing leukocyte protein (SLP) adaptor is the universal TLR adaptor for TLR2, TLR3, TLR4, and TLR9, and the C-terminal Src kinase (CSK)-interacting membrane protein (SCIMP) presents Lyn and other effectors, such as Csk, Gdb2, and Slp65, to TLRs during cellular activation.

\section{TLR3-TRIF signaling pathway}

\subsection{Overview of TLR3-TRIF signaling pathway}

Upon activation, TLR3 recruits TRIF to trigger a downstream signaling cascade (Matsumoto et al., 2011). Unlike other TLR family members, TLR3 is utterly dependent on TRIF (Yang and Shu, 2020). The TLR3-TRIF signaling pathway involves signal transduction by TRAF3/6, TRAF family member-associated NF- $\kappa B$ activator (TANK)-binding kinase 1 (TBK1), inhibitor of $\kappa \mathrm{B}(\mathrm{I} \kappa \mathrm{B})$ kinase-related kinase- $\varepsilon$ (IKK- $\varepsilon$; also called IKK-i), receptor-interacting protein-1 (RIP-1), and NF- $\kappa$ B-activating kinase (NAK)-associated protein 1 (NAP1). This signaling pathway ultimately activates transcription factors, namely IRF3/7, NF- $\kappa B$, and the activator protein 1 (AP-1), thus mediating the production of type I IFNs, proinflammatory cytokines, and chemokines, respectively, following TLR3 activation. Phosphoinositide 3-kinase (PI3K), p38-mitogenactivated protein kinase (MAPK), extracellular signalregulated kinase (ERK), and c-Jun N-terminal kinase (JNK) are also activated by TLR3 signaling (Schröder and Bowie, 2005). TLR3-induced MAPKs are responsible for activating AP-1, and PI $3 \mathrm{~K}$ is crucial for full phosphorylation and activation of IRF3 (Ameyar et al., 2003; Sarkar et al., 2004). Ubiquitination and phosphorylation play an indispensable role in the finetuning of the TLR3 signaling cascade. The general scenario of the TLR3-TRIF signaling pathway is described in Fig. 2a.

The TRIF gene of humans is located on chromosome 19p13.3 and encodes 712 amino acids, making it much larger than the other TIR domain-containing linker proteins (Mahita and Sowdhamini, 2017). TRIF consists of an $\mathrm{N}$-terminal protease-resistant domain (1-153 amino acids (aa)), an intermediate disordered proline-rich region (154-392 aa), a TIR domain (393$545 \mathrm{aa}$ ), and a C-terminal region (containing an RIP homotypic interaction motif (RHIM) domain, 661699 aa) (Mahita and Sowdhamini, 2017) (Fig. 2b). The N-terminal region is involved in TRIF-mediated IRF3 activation, the C-terminal region is crucial for NF- $\mathrm{KB}$ activation and apoptosis, while the TIR domain is essential for binding to TLR3 (Tatematsu et al., 2010; Kumeta et al., 2014; Patra et al., 2020). The disordered region between the N-terminal domain and the TIR domain contains binding sites for many downstream proteins such as TBK1, TRAF2 (332-336 aa), and TRAF6 (TRAF6-binding motif 2 (T6BM) domain, 248-256 aa) (Sasai et al., 2010). Mahita and Sowdhamini (2017) proved that the Nterminal domain binds to the BB-loop region of the TIR domain to prevent TLR3 homodimerization. The physical association between TRAF3 and TRIF has always been controversial. Many conflicting data about their physical association have been reported (Sasai et al., 2010). However, a recent report indicated that the 21 amino acid sequences $(160-181$ aa) from the amino-terminal half of TRIF are crucial for the TRAF3 


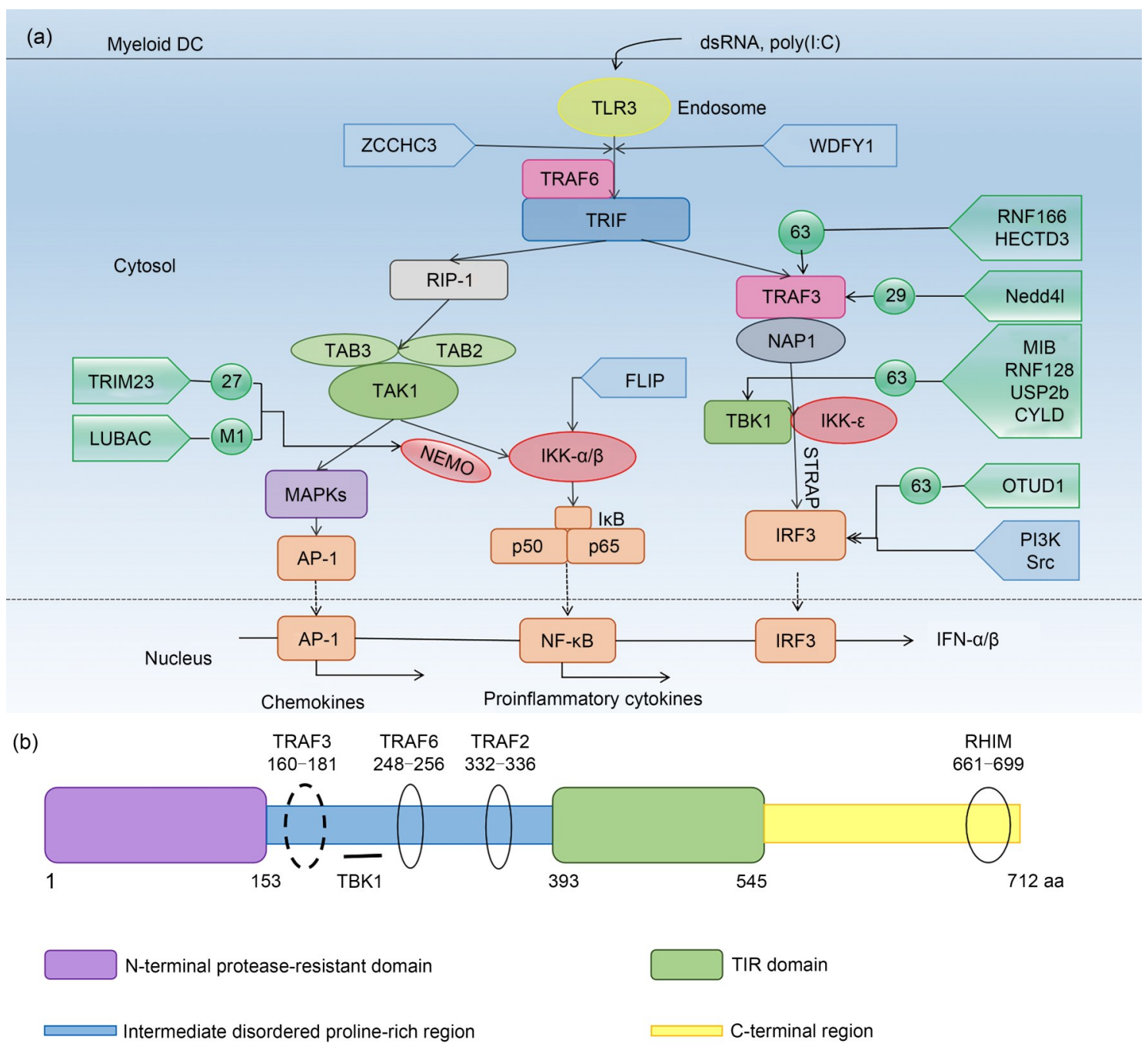

Fig. 2 Mechanism of the Toll-like receptor 3 (TLR3)-Toll-interleukin-1 receptor (TIR)-domain-containing adaptorinducing interferon- $\beta$ (IFN- $\beta$ ) (TRIF) signaling pathway and structure of human TRIF. (a) Mechanism of the TLR3TRIF signaling pathway. After double-stranded RNA (dsRNA) activates endosomal TLR3, TRIF transiently colocalizes with TLR3; it dissociates from the receptor and forms a speckle-like structure that relocalizes with downstream-signaling molecules such as tumor necrosis factor (TNF) receptor-associated factor 2 (TRAF2), TRAF6, and receptor-interacting protein-1 (RIP-1) (Funami et al., 2004, 2007). Then, with the cooperation of TRAF3, TRAF family member-associated

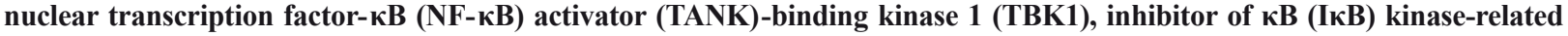
kinase- $\varepsilon$ (IKK- $\varepsilon$; also called IKK-i), and NF-KB-activating kinase (NAK) -associated protein 1 (NAP1), this signaling pathway ultimately activates transcription factors, namely IFN-regulatory factor 3/7 (IRF3/7), the TRIF-dependent NF$\kappa \mathrm{B}$, and the activator protein 1 (AP-1), thus mediating the production of type I IFNs, proinflammatory cytokines, and chemokines, respectively. (b) Schematic structure of human TRIF. TRIF consists of an N-terminal protease-resistant domain (1-153 amino acids (aa)), an intermediate disordered proline-rich region (154-392 aa), a TIR domain (393-545 aa), and a C-terminal region (containing a RIP homotypic interaction motif (RHIM) domain, 661-699 aa) (Mahita and Sowdhamini, 2017). The disordered region between the N-terminal domain and the TIR domain contains binding sites for many downstream proteins such as TBK1, TRAF2 (332-336 aa), and TRAF6 (248-256 aa) (Sasai et al., 2010). The physical association between TRAF3 and TRIF is controversial (Nguyen et al., 2014). ZCCHC3: zinc finger CCHC-type containing 3; WDFY1: WD-repeat- and FYVE-domain-containing protein 1; TRIM23: tripartite motif-containing protein 23; LUBAC: linear ubiquitin chain assembly complex; RNF166: ring finger protein 166; HECTD3: E6-associated protein carboxyl terminus domain containing 3; Nedd4l: neural precursor cell expressed developmentally down-regulated 4-like; MIB: mind bomb; RNF128: RING finger 128; USP2b: ubiquitin-specific protease 2 isoform b; CYLD: conserved cylindromatosis; OTUD1: termed OTU domain-containing protein 1; PI3K: phosphoinositide 3-kinase; NEMO: NF- $\kappa B$ essential modifier; MAPK: p38-mitogen-activated protein kinase; FLIP: viral FLICE-like inhibitory protein. 
association and modulating TRIF ubiquitination and degradation (Nguyen et al., 2014). TRIF with a 21residue deletion $(\Delta 160-181)$ inefficiently transactivated the IFN pathway, and its association with TRAF3 was weaker than that of wild-type (WT) TRIF (Nguyen et al., 2014).

Funami et al. (2016) demonstrated that 14-3-3- $\zeta$ acts as a novel component of the TRIF signalosome that functions in TLR3-mediated signaling. With the ablation of the TRIF signalosome in 14-3-3- $\zeta$-knockdown cells, the synthesis of IFN and inflammatory cytokines decreased, and TLR3-mediated IRF3 translocation, as well as $\mathrm{IkB} \alpha$ phosphorylation, was diminished. The identification of $14-3-3-\zeta$ has shed new light on TRIF signaling.

\subsection{Activation mechanism of the TLR3-TRIF signaling pathway}

\subsubsection{Recruitment of TRIF}

TRIF is expressed at a low level in most tissues and cells, and exists diffusely in the cytoplasm of resting cells (Funami et al., 2016). After dsRNA activates endosomal TLR3, TRIF transiently colocalizes with TLR3; it dissociates from the receptor and alters its distribution profile from a diffuse cytoplasmic pattern to a speckle-like structure that relocalizes with downstreamsignaling molecules (Funami et al., 2004, 2007). Both TLR3 and TRIF contain a TIR domain, which is crucial to their interaction once TLR3 binds to the ligand (Oshiumi et al., 2003). The TIR domain of TLR3 has three highly conserved sequences, Box 1 , Box 2 , and Box3; Box 2 constitutes the BB loop, which is crucial for binding downstream linker proteins (Singh et al., 2014). Unlike other TLRs, the BB loop in binding TRIF does not contain conservative proline residues, but is replaced by alanine, which is critical for binding TRIF. The TLR3 mutant A795H (TLR3 with Ala795His mutation) has lost the ability to bind to TRIF (Oshiumi et al., 2003).

A recent report indicated that WD-repeat- and FYVE-domain-containing protein 1 (WDFY1) acts as a critical adaptor protein during TLR3 recruitment of TRIF by associating with the TIR domain of TLR3 (Hu et al., 2015). Their interaction depends on the tyrosine phosphorylation of TLR3. Zinc finger CCHC-type containing 3 (ZCCHC3) is also a critical component of the TLR3-TRIF signaling pathway, and facilitates the recruitment of TRIF to TLR3 after
poly(I: C) stimulation (Zang et al., 2020). The Nterminal domain (1-300 aa) and C-terminal domain (300-404 aa) of ZCCHC3 are functional for its interaction with the N-terminal/TIR domains of TRIF and the TIR domain of TLR3, respectively.

\subsubsection{TRIF-dependent activation of IRF3}

IRF3 and another IRF family member IRF7, are known to be IFN regulatory factors $(\mathrm{Wu}$ and Chen, 2014). Both mediate the activation of NF- $\mathrm{KB}$, but IRF3 is activated by the TRIF pathway and IRF7 by the MyD88 pathway (Kawai and Akira, 2010). In inactivated cells, IRF3 is phosphorylated to form the IRF3:IRF3 homodimer or the IRF3:IRF7 heterodimer, which enters the nucleus and leads to specific gene expression (Schmid et al., 2014). TRIF-mediated IRF3 activation is regulated by the protein kinases IKK- $\varepsilon$ and TBK1. Activation may depend on upstream linker proteins, NAP1, TANK, and SINTBAD (similar to NAP1 TBK1 adaptor) (Tatematsu et al., 2010; Schmid et al., 2014). NAP1, TANK, and SINTBAD are similar in structure. NAP1 participates in the recruitment of IRF3 kinases to the N-terminal region of TRIF. TANK, as a binding ligand of TBK1, IKK- $\varepsilon$, and the TRAF family, is responsible for associating TRAF3 with TBK1 and IKK- $\varepsilon$ (Ryzhakov and Randow, 2007).

TRIF is homo-oligomerized at the Pro434 residue in the TIR domain and the C-terminal region. The recruitment of TRAF3 by TRIF is essential for the activation of IRF3 (Funami et al., 2008). TRAF3 undergoes a Lys63-linked poly-ubiquitination with the synergy of the E2 ubiquitin-conjugating enzyme Ubc13/ Uev5 (Zeng et al., 2009; Tseng et al., 2010). Then, ubiquitinated TRAF3 mediates oligomerization of TBK1 and IKK- $\varepsilon$ via adaptor proteins such as TANK and NAP1 (Guo and Cheng, 2007; Tatematsu et al., 2010). TBK1 and IKK- $\varepsilon$ are responsible for phosphorylation and activation of IRF3 (Zhou et al., 2020). The phosphorylated IRF3 dimerizes and translocates to the nucleus to initiate the transcription of the IFN- $\beta$ gene (Honda et al., 2006). The activation, regulation, substrate, and function of TBK1 and IKK- $\varepsilon$ remain to be elucidated.

c-Src tyrosine kinase is activated by dsRNA in human DCs, and then is recruited to TLR3 (Johnsen et al., 2006). In Src kinase-deficient cells, dsRNAinduced activation of IRF3 and activator of transcription 1 
is abolished. Phosphorylation of TLR3 on tyrosine 759 increases in parallel to Src-dependent IFN- $\beta$ production (Zhang et al., 2016). Serine/threonine kinase receptor-associated protein (STRAP) acts as a scaffold protein in TLR3-triggered signaling (Huh et al., 2017), and strongly interacts with TBK1 and IRF3 to enhance IFN- $\beta$ production. K63-linked poly-ubiquitination of TRAF3 is promoted by overexpression of the E3 ligase ring finger protein 166 (RNF166) following Sendai virus (SeV) infection (Chen et al., 2015). The E6-associated protein carboxyl terminus domain containing 3 (HECTD3) also acts as an E3 ligase catalyzing this poly-ubiquitination during bacterial infection, but the exact function of HECTD3 during viral infection is poorly understood (Li et al., 2018). Neural precursor cell-expressed developmentally downregulated 4-like (Nedd4l) promotes TRAF3-mediated signal transduction by catalyzing K29-linked ubiquitination at the $\mathrm{C} 56$ and $\mathrm{C} 124$ cysteine residues of TRAF3 (Liu, 2019). E3 ubiquitin ligases, mind bomb (MIB) and RING finger 128 (RNF128), promote the K63-linked poly-ubiquitination of TBK1 for its activation (Li et al., 2011; Song et al., 2016). In addition to E3 ligases, the deubiquitinating enzymes (DUBs) ubiquitin-specific protease 2 isoform $b$ (USP2b) and the conserved cylindromatosis (CYLD) target TBK1 for K63-linked deubiquitination, and OTU domaincontaining protein 1 (OTUD1) cleaves the K63-linked polyubiquitin chains from IRF3 (Lu et al., 2018).

TRIF and two other adaptor proteins, stimulator of IFN genes (STING) and mitochondrial antiviral signaling (MAVS), mediate the recruitment of IRF3 via a conserved pLxIS motif, the same motif as that of IRF3 (Zhao BY et al., 2016). The pLxIS motifs of the three adaptor proteins are phosphorylated by TBK1 or IKK- $\varepsilon$ (Zhao BY et al., 2016). A recent paper demonstrated that phosphorylated TRIF, MAVS, and STING bind to a positively charged surface of IRF3 and thus recruit IRF3 for activation by TBK1 (Liu et al., 2015). TRIF is phosphorylated at its consensus motif S210/S212/T214 by TBK1, and TRIF S210 is the critical phosphorylation site for IRF3 activation.

\subsubsection{TRIF-dependent activation of NF- $\mathrm{kB}$}

$\mathrm{NF}-\kappa \mathrm{B}$ is a central transcription factor crucial to innate and adaptive immunities, cell proliferation, apoptosis, and the stress response (Cartwright et al., 2016). The $\mathrm{p} 50 / \mathrm{p} 65$ heterodimer of NF- $\kappa \mathrm{B}$ activates the expression of IFN- $\beta$ and proinflammatory cytokines (Kawai and Akira, 2007; Kohl et al., 2019). The K63linked polyubiquitin chains of RIP-1 and TRAF6 can recruit the transforming growth factor- $\beta$ (TGF- $\beta$ )activated kinase 1 (TAK1)-TAK1-binding protein 2 (TAB2)-TAB3 complex via the ubiquitin-binding activity of TAB2/3, causing TAK1 autophosphorylation and activation (Yang and Shu, 2020). TAK1 activates the IкB kinase complex, which consists of the IKK- $\alpha$ and IKK- $\beta$ kinases scaffolded by NF- $\kappa B$ essential modifier (NEMO), ultimately activating NF- $\mathrm{KB}$ or stimulating MAPK-mediated AP-1 transcriptional responses (Emmerich et al., 2013; Mitchell et al., 2016). RIP-1 associates with TRIF via the RHIM domain at the C-terminal of TRIF followed by RIP-1 interaction with TNF receptor-associated death domain (TRADD) protein. TRADD is an adaptor protein related to the ubiquitination of RIP-1, via the homotypic death domain (Meylan et al., 2004; Ermolaeva et al., 2008; Park et al., 2015). TRAF6 binds with the T6BM domain in the N-terminal region of TRIF to mediate NF- $\mathrm{KB}$ activation (Mahita and Sowdhamini, 2017). In addition, TRAF6 mediates the recruitment of meddlesome-associated TBK1 to stimulate the rapid induction of glycolysis following TLR3 activation (Tan and Kagan, 2019). The rapid glycolysis drives metabolic changes in the cell, resulting in an increased need for histone modifications related to durable transcriptional activities in the nucleus or enhanced protein synthesis and secretory activities associated with TLR3 signaling (Corcoran and O'Neill, 2016; Langston et al., 2019).

The activation of the NF- $\mathrm{kB}$ signaling pathway is a sign of viral infection. Once NF- $\mathrm{kB}$ is activated, it up-regulates many cytokines and chemokines (such as TNF- $\alpha$ and IL-6), which give positive feedback through the NF- $\kappa B$ pathway, thereby amplifying the initial inflammatory signal. The activation of NF- $\mathrm{KB}$ is influenced by many regulators that act on adaptor proteins and kinases of the NF- $\mathrm{KB}$ pathway. The E3 ligase TRIM23 regulates the activation of NEMO by atypical K27-linked poly-ubiquitination, and the linear ubiquitin chain assembly complex (LUBAC), another E3 ligase, catalyzes the linear ubiquitination of NEMO at K285 and K309 (Zheng and Gao, 2020). The viral FLICE-like inhibitory protein (FLIP) forms a stable complex with a central region of the inhibitor of IKK- $\gamma$ and activates the NF- $\mathrm{KB}$ pathway via IKK activation (Baratchian et al., 2016). 


\section{Negative regulation of TLR3 signaling}

The PRR pathways are controlled by many external and intracellular molecules to maintain a balance between activation and inhibition, thus balancing the beneficial and adverse effects of antigen detection (Antosz and Choroszyńska, 2013). The mechanism of negative regulation with TLR is most developed in immune cells. It is strictly limited to a specific TLR and operates at multiple levels of TLR signaling. Here, we focus on TLR3-negative regulators, which inhibit signals at different stages of activation (Fig. 3).

\subsection{Negative regulation of ubiquitination modifying enzymes}

E3 ubiquitin ligases and deubiquitinases (DUBs), as the master regulators of TLR signaling, cooperatively regulate the dynamic and reversible ubiquitination process (Zheng and Gao, 2020).

The TLR3-binding E3 ligase RNF170 mediates the K48-linked poly-ubiquitination of K766 in the TIR domain of TLR3 (Song et al., 2020). RNF170 promotes the degradation of TLR3 via the proteasome pathway, thus selectively inhibiting TLR3-mediated pathways (Song et al., 2020). TRIM38 associates with

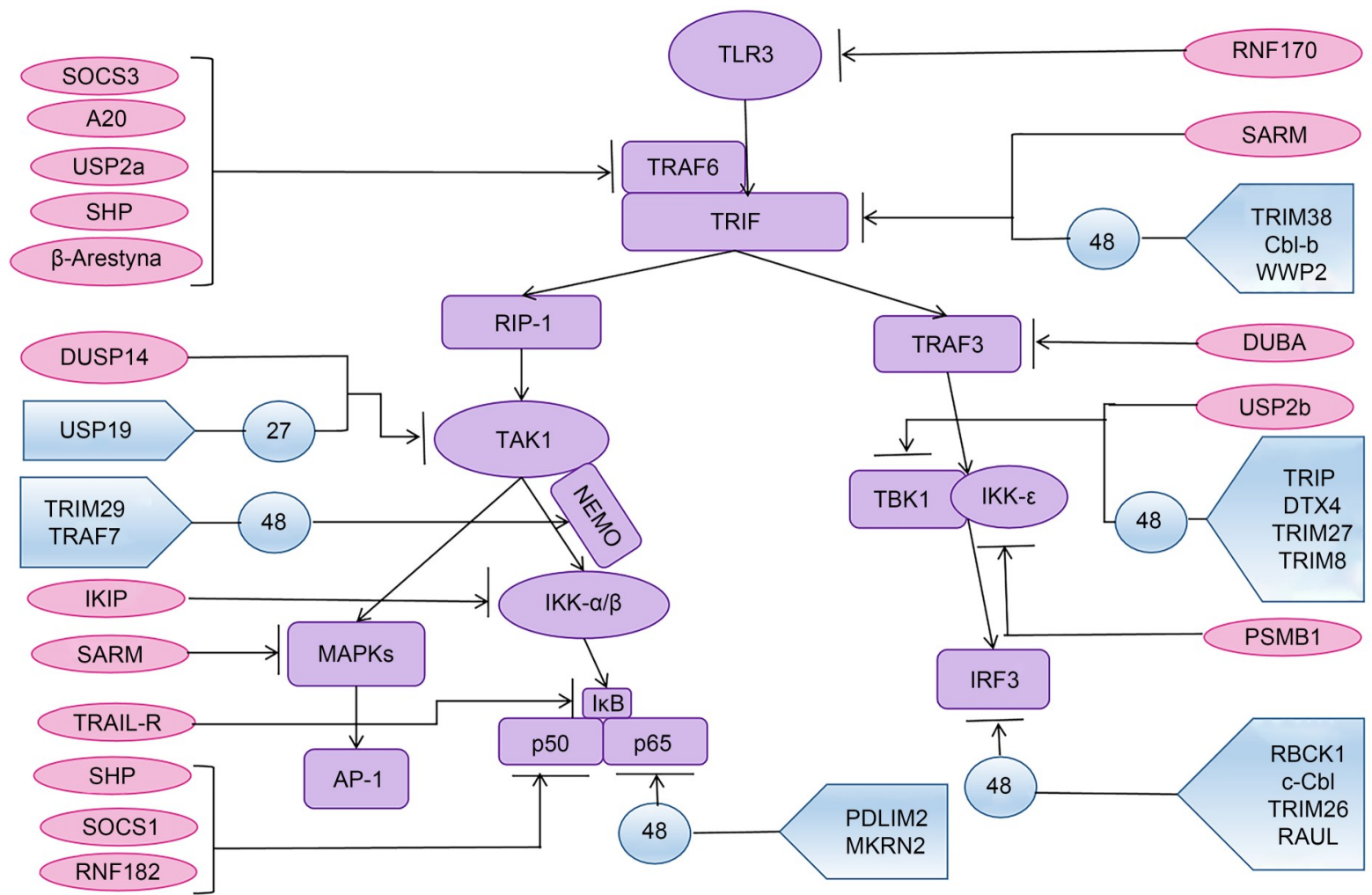

Fig. 3 Negative regulation of TLR3 signaling. The trunk of the TLR3-TRIF signaling pathway is shown in purple; ubiquitination modifying enzymes that negatively regulate the pathway are in blue; other negative regulators, such as membrane proteins, adaptor proteins, and phosphatases, are in pink. AP-1: activator protein 1; c-Cbl: Casitas B-lineage lymphoma; DTX4: Deltex 4; DUBA: deubiquitinating enzyme A; DUSP14: dual-specificity phosphatase 14; IкB: inhibitor of кB; IKK: IKB kinase-related kinase; IKIP: IKK-interacting protein; IRF3: interferon (IFN)-regulatory factor 3; MAPK:

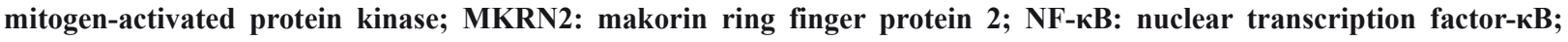
NEMO: NF- $\kappa B$ essential modifier; PDLIM2: PDZ and LIM domain-containing protein 2; PSMB: proteasome $\beta$ subunit; RAUL: transcriptional activator (RTA)-associated ubiquitin ligase; RBCK1: RBCC protein interacting with PKC1; RIP-1: receptor-interacting protein-1; RNF: ring finger protein; SARM: sterile $\alpha$ and HEAT/Armadillo motif; SHP: small heterodimer partner; SOCS: suppressor of cytokine signaling; TGF- $\beta$ : transforming growth factor- $\beta$; TAK1: TGF- $\beta$-activated kinase 1; TLR3: Toll-like receptor 3; TNF: tumor necrosis factor; TRAF: TNF receptor-associated factor; TBK1: TRAF family member-associated NF- $\mathrm{KB}$ activator (TANK)-binding kinase 1; TRAIL: TNF-related apoptosisinducing ligand; TRIF: Toll-interleukin-1 receptor (TIR)-domain-containing adaptor-inducing IFN- $\beta$; TRIM: tripartite motif-containing protein; TRIP: TRAF-interacting protein; USP2a: ubiquitin-specific protease 2 isoform a; USP19: ubiquitin-specific protease 19; WWP2: WW domain-containing protein 2. 
the N-terminus of TRIF through its PRYSPRY domain to mediate K48-linked poly-ubiquitination and degradation of TRIF. Other proteins involved in this process are WW domain-containing protein 2 (WWP2) and Casitas B-lineage lymphoma (c-Cbl) (Han et al., 2010; Xue et al., 2012; Yang et al., 2013).

The E3 ubiquitin ligases TRAF-interacting protein (TRIP), Deltex4 (DTX4), TRIM27, and TRIM8 are responsible for modulating the turnover of TBK1 through K48-linked poly-ubiquitination (Cui et al., 2012; Zhang et al., 2012; Zheng et al., 2015; Ye et al., 2017). The E3 ligases RBCC protein interacting with PKC1 (RBCK1), c-Cbl, TRIM26, and RNA transcriptional activator (RTA)-associated ubiquitin ligase (RAUL) target the nuclear IRF3 for K48-linked polyubiquitination and degradation ( $\mathrm{Yu}$ and Hayward, 2010; Wang et al., 2015; Zhao XB et al., 2016).

E3 ligase ubiquitin-specific protease 19 (USP19) induces deconjugation of K63- and K27-linked polyubiquitin chains from TAK1, resulting in disruption of the TAK1-TAB2/3 complex (Lei et al., 2019). Additionally, USP19 impairs the recruitment of TRIF to TLR3/4 by catalyzing the removal of TRIF K27-linked polyubiquitin moieties (Wu X et al., 2019). TRIM29 and TRAF7 promote the turnover of NEMO by facilitating the K48- and K29-linked poly-ubiquitination of NEMO, respectively (Xing et al., 2016). Makorin ring finger protein 2 (MKRN2) and PDZ and LIM domain-containing protein 2 (PDLIM2) cooperatively promote the K48-linked poly-ubiquitination and proteasomal degradation of nuclear p65 (Shin et al., 2017). RNF182 can also contribute to the degradation of p65 via K48-linked ubiquitination, thus inhibiting TLR3triggered proinflammatory responses (Cao Y et al., 2019).

DUBs, such as A20, deubiquitinating enzyme A (DUBA), and USP2, are reported to be involved in the type I IFN pathway. Zinc-finger protein A20 is a negative regulator that regulates both MyD88- and TRIF-dependent TLR signaling pathways (Saitoh et al., 2005). Saitoh et al. (2005) reported that A20 negatively regulates TLR3-mediated $I F N-\beta$ gene transcription by inhibiting IRF3 activation. A20 also prevents NF- $\kappa$ B activation via the A20-TRAF6 axis (Boone et al., 2004). DUBA negatively regulates TLR3-mediated type I IFN production by selectively cleaving the Lys63-linked polyubiquitin chains on TRAF3 (Kayagaki et al., 2007). USP2a negatively regulates NF- $\kappa$ B activation by cleaving K63-linked polyubiquitin chains on TRAF6 (He et al., 2013). USP2b targets TBK1 and deubiquitinates TBK1 K63-linked poly-ubiquitination, thus negatively modulating the TLR3/4 signaling pathway (Zhang et al., 2014).

The members of the suppressor of cytokine signaling (SOCS) family also participate in immune response regulation (Antosz and Choroszyńska, 2013). SOCS1 targets the subunit p65 (RelA)-NF- $\kappa \mathrm{B}$ and leads to proteolysis of the NF- $\kappa \mathrm{B}$ molecule by ubiquitination (Ryo et al., 2003). SOCS3 represses TRAF6 activation to block the subsequent activation of TAK1, which must activate both the NF- $\mathrm{B}$ and MAPK pathways (Frobøse et al., 2006).

\subsection{Negative regulation of membrane proteins}

The TNF-related apoptosis-inducing ligand (TRAIL) cytokine was identified as a member of the TNF superfamily which initiates the apoptotic pathway in many cancer cell lines (Yuan et al., 2018). Diehl et al. (2004) claimed that TRAIL-R inhibits TLR signaling by stabilizing $\operatorname{IkB} \alpha$ and decreasing the expression of the transcription factor $N F-\kappa B$, and showed that TLR2, TLR3, and TLR4 ligands bolster the expression of TRAIL-R. In contrast, in the case of TRAIL-R deficit, there is an increased production of cytokines in response to these ligands (Diehl et al., 2004).

\subsection{Negative regulation of adaptor proteins}

$\beta$-Arrestin 1 and $\beta$-arrestin 2 are ubiquitously expressed multifunctional scaffolding proteins that affect inflammatory signaling in various cell lines (Freedman and Shenoy, 2018). $\beta$-Arrestins participate in intracellular signaling by playing a role as MAPK scaffolds or mediating Src activation (Laporte and Scott, 2019). Witherow et al. (2004) indicated that $\beta$-arrestin is involved in modulating TLR signaling by affecting $N F-\kappa B$ activation. Research by Wang et al. (2006) showed that $\beta$-arrestin interacts with TRAF6 via the TIR domain, thus preventing the auto-ubiquitination and oligomerization of TRAF6 required for the activation of NF- $\kappa \mathrm{B}$ and AP-1.

Sterile $\alpha$ and HEAT/Armadillo motif (SARM), the most conserved member of the TIR adaptor family, is located in the cytoplasm and directly affects the cytosol TRIF, decreasing NF- $\mathrm{BB}$ and IRF3, and thus negatively regulates TRIF-dependent signaling 
induced by TLR3 and TLR4 (Carty and Bowie, 2019). Research by Peng et al. (2010) showed that, in human cells, SARM blocks the TRIF- and MyD88dependent activation of AP-1 and the endogenous form of AP-1.

\subsection{Negative regulation of phosphatases}

Small heterodimer partner (SHP) is also a negative TLR signaling regulator (Zhang and Shen, 2011). In resting cells, SHP inhibits NF-kB-dependent signaling by interacting with p65-NF- $\mathrm{kB}$ (Zhang and Shen, 2011). Upon stimulation, SHP decreases the TRAF6 Lys63-link polyubiquitin by interacting with the RING TRAF6 domain (Yuk et al., 2011). DUSP14, a member of the dual-specificity phosphatase (DUSP) family, represses TNF- and IL-1 $\beta$-triggered NF- $\mathrm{KB}$ activation by dephosphorylating TAK1 T187 (Zheng et al., 2013).

\subsection{Other negative regulators}

PSMB1 is a proteasome $\beta$ subunit (PSMB) family member, which inhibits the TLR and RLR signaling pathways (Sorokin et al., 2009; Wu FY et al., 2019). The silencing of PSMB1 increases IFN- $\beta$ production, whereas overexpression of PSMB1 inhibits activation of virus-induced IFN- $\beta$ promoter (Wu FY et al., 2019). PSMB1 promotes the degradation of IKK- $\varepsilon$ by interacting with IKK- $\varepsilon$ through the ubiquitin-proteasome system (Wu FY et al., 2019). IKK-interacting protein (IKIP) inhibits the formation of IKK complex by binding to IKK- $\alpha / \beta$ in competition with NEMO, thus hindering the phosphorylation of IKK- $\alpha / \beta$ and negatively regulating the activation of the downstream NF- $\mathrm{kB}$ signaling pathway (Wu HF et al., 2020). In the presence of lipopolysaccharide (LPS), poly(I: C), TNF- $\alpha$, and IL-1 $\beta$ stimulation, the phosphorylation of IKK- $\alpha / \beta$, $\mathrm{I} \kappa \mathrm{B}$, and $\mathrm{p} 65$ is enhanced, and the expression of TNF- $\alpha$ and IL- 6 is increased in the macrophages of IKIP-deficient mice (Wu HF et al., 2020).

The signals transmitted from TLR are controlled by specific inhibitors, which show tissue and cellular specificity in many cases. However, the mechanisms underlying this specificity are poorly understood. Many inhibitory factors known to affect TLR signaling have yet to be evaluated.

\section{Antiviral effects of TLR3}

TLR3 may be a double-edged sword that functions in ensuring or compromising host immunity against viruses (Perales-Linares and Navas-Martin, 2013) (Table 1). TLR3-mediated signaling during viral infections protects against correlative diseases by reducing the viral loads and modulating immune responses, while over-activation of the pathogenic immune response induced by TLR3 signal transduction can lead to pathogenesis (Perales-Linares and Navas-Martin, 2013). Thus, the tight balance between a controlled antiviral response and excessive immune activation determines the pathological outcome of TLR3-related diseases. The TLR3 pathway can control immunity to most of the clinically relevant viral infections in humans, including those caused by flaviviruses, hepatitis viruses, RV, herpesvirus, retroviruses, encephalomyocarditis virus, orthomyxoviruses, and the currently epidemic severe acute respiratory syndrome coronavirus 2 (SARS-CoV-2).

Table 1 Roles of TLR3 in antiviral responses

\begin{tabular}{|c|c|c|c|c|}
\hline Effect & Virus & Target organ & Disease & Role of TLR3 \\
\hline \multirow[t]{4}{*}{ Protection } & $\begin{array}{l}\text { Herpes simplex virus } \\
\text { type } 1 \text { (HSV-1) }\end{array}$ & $\begin{array}{l}\text { Central nervous } \\
\text { system (CNS) }\end{array}$ & $\begin{array}{l}\text { Encephalitis or } \\
\text { others }\end{array}$ & $\begin{array}{l}\text { TLR3 recruits the metabolic checkpoint kinase } \\
\text { complex mTORC2, thus enabling the activation } \\
\text { of molecules (including mTORC1) required for } \\
\text { type I IFN induction (Mielcarska et al., 2018). }\end{array}$ \\
\hline & $\begin{array}{l}\text { Encephalomyocarditis } \\
\text { virus (EMCV) }\end{array}$ & $\begin{array}{l}\text { Myocardium, } \\
\text { brain }\end{array}$ & $\begin{array}{l}\text { Encephalomyo- } \\
\text { carditis }\end{array}$ & $\begin{array}{l}\text { TLR3 decreases viral replication in the heart, and } \\
\text { decreases myocardial injury (Hardarson et al., 2007). }\end{array}$ \\
\hline & $\begin{array}{l}\text { Coxsackievirus strain B } \\
\text { serotype } 3(\mathrm{CVB} 3)\end{array}$ & $\begin{array}{l}\text { Myocardium, } \\
\text { meninges, } \\
\text { pancreas }\end{array}$ & $\begin{array}{l}\text { Acute and chronic } \\
\text { myocarditis, } \\
\text { meningitis, and } \\
\text { pancreatitis }\end{array}$ & $\begin{array}{l}\text { TLR3 resists CVB3 infection and prevents the } \\
\text { progression from myocarditis to iDCM (Abston } \\
\text { et al., 2013; Sesti-Costa et al., 2017). }\end{array}$ \\
\hline & $\begin{array}{l}\text { Murine cytomegalovirus } \\
\text { (MCMV) }\end{array}$ & Liver & Hepatitis & $\begin{array}{l}\text { Cytokine (type I IFN, IFN- } \gamma \text {, and IL-12p40) } \\
\text { production, and NK cell and NKT cell activation } \\
\text { are impaired in TLR3-deficient mice compared } \\
\text { with wild-type mice (Matsumoto et al., 2011). }\end{array}$ \\
\hline
\end{tabular}


Table 1

\begin{tabular}{|c|c|c|c|c|}
\hline Effect & Virus & Target organ & Disease & Role of TLR3 \\
\hline & Rotavirus (RV) & Kidney & Glomerulonephritis & $\begin{array}{l}\text { TLR3 plays a synergistic role with protective factors } \\
\text { and down-regulates the expression of cytokines } \\
\text { induced by RV (Jiang et al., 2017). }\end{array}$ \\
\hline & Poliovirus (PV) & Bone marrow & Poliomyelitis & $\begin{array}{l}\text { TLR3-TRIF signaling pathway governs IFN } \\
\text { induction and host protection against PV } \\
\text { infection (Oshiumi et al., 2011). }\end{array}$ \\
\hline & $\begin{array}{l}\text { Human immunodeficiency } \\
\text { virus } 1 \text { (HIV-1) }\end{array}$ & $\begin{array}{l}\mathrm{CD}^{+} \text {and } \\
\mathrm{CD} 8^{+} \mathrm{T} \text { cells, } \\
\text { macrophages, } \\
\text { others }\end{array}$ & $\begin{array}{l}\text { Immunodeficiency, } \\
\text { encephalitis, } \\
\text { and others }\end{array}$ & $\begin{array}{l}\text { TLR3 decreases HIV-1 infection in macrophages } \\
\text { and enhances the development of HIV-specific } \\
\text { CD } 4^{+} \text {and CD } 8^{+} \text {cytotoxic T lymphocytes (Cheng } \\
\text { et al., 2018; Nguyen et al., 2020). }\end{array}$ \\
\hline & $\begin{array}{l}\text { Severe acute respiratory } \\
\text { syndrome coronavirus } \\
2 \text { (SARS-CoV-2) }\end{array}$ & $\begin{array}{l}\text { Respiratory } \\
\text { tract }\end{array}$ & $\begin{array}{l}\text { Coronavirus } \\
\text { disease 2019 } \\
\text { (COVID-19) }\end{array}$ & $\begin{array}{l}\text { TLR3- and IRF7-dependent type I IFN immunity } \\
\text { may be essential for preventing life-threatening } \\
\text { COVID-19 pneumonia (Zhang et al., 2020). }\end{array}$ \\
\hline & Influenza A virus (IAV) & CNS, brain & Encephalopathy & $\begin{array}{l}\text { TLR3 signaling pathways are activated preferentially } \\
\text { following IAV infection to release a range of } \\
\text { proinflammatory cytokines (Huo et al., 2018). }\end{array}$ \\
\hline Deterioration & Phlebovirus & Liver & Hepatopathy & $\begin{array}{l}\text { Compared with TLR3-deficient mice, wild-type } \\
\text { mice demonstrate decreased resistance to lethal } \\
\text { infection. The result may be caused by overpro- } \\
\text { duction of inflammatory mediators via TLR3 } \\
\text { signaling (Gowen et al., 2006). }\end{array}$ \\
\hline \multirow[t]{4}{*}{ Bi-direction } & Hepatitis $\mathrm{C}$ virus (HCV) & Liver & Hepatitis C & $\begin{array}{l}\text { Protection: TLR3 inhibits HCV replication in Huh7 } \\
\text { cells (Zhou et al., 2016). } \\
\text { Deterioration: TLR3 possibly contributes to the } \\
\text { intrahepatic and unbalanced proinflammatory } \\
\text { response (Li et al., 2012). }\end{array}$ \\
\hline & Hepatitis B virus (HBV) & Liver & Hepatitis & $\begin{array}{l}\text { Protection: TLR3-knockout mice are unable to } \\
\text { express IL-8 and other requisite molecules to } \\
\text { activate immune responses against HBV (Maire } \\
\text { et al., 2008). Activation of mDC using TLR3 } \\
\text { ligands leads to improved NK cell function in } \\
\text { CHB infection (Tjwa et al., 2012). } \\
\text { Deterioration: TLR3 polymorphism rs3775291 was } \\
\text { associated with an increased risk of developing } \\
\text { CHB (Geng et al., 2016; Fischer et al., 2018). }\end{array}$ \\
\hline & West Nile virus (WNV) & Brain & Encephalitis & $\begin{array}{l}\text { Protection: TLR3 restricts WNV replication in } \\
\text { neurons and antagonizes against NS1 (Daffis } \\
\text { et al., 2008; Wilson et al., 2008). }\end{array}$ \\
\hline & & & & $\begin{array}{l}\text { Deterioration: compared with TLR3-deficient mice, } \\
\text { wild-type mice are less resistant to lethal WNV } \\
\text { infection (Wang et al., 2004). Increased frequency of } \\
\text { WNV encephalitis in elderly humans may be related } \\
\text { to increased TLR3 signaling (Kong et al., 2008). }\end{array}$ \\
\hline \multirow[t]{2}{*}{ Unclear } & Influenza A (H1N1) & Lung & Pneumonia & $\begin{array}{l}\text { The presence of TLR } 3 \text { rs } 5743313 / \mathrm{CT} \text { polymorphism } \\
\text { has a close relationship with the increased risk of } \\
\text { pneumonia in children infected by the pandemic } \\
\text { A/H1N1/2009 (Esposito et al., 2012). TLR3 does } \\
\text { not worsen the pathogenesis of pH1N1 infection } \\
\text { (Leung et al., 2014). }\end{array}$ \\
\hline & $\begin{array}{l}\text { Tick-borne encephalitis } \\
\text { virus (TBEV) }\end{array}$ & $\mathrm{CNS}$ & Encephalitis & $\begin{array}{l}\text { TLR3 may be a risk factor for TBEV infection } \\
\text { (Kindberg et al., 2011). }\end{array}$ \\
\hline
\end{tabular}

CD: cluster of differentiation; CHB: chronic hepatitis B; iDCM: inflammatory dilated cardiomyopathy; IFN: interferon; IL: interleukin; IRF: IFN-regulatory factor; mDC: myeloid dendritic cell; mTORC: mammalian target of rapamycin complex; NK: natural killer; NKT: natural killer T; NS1: non-structural protein 1; pH1N1: pandemic H1N1 influenza; TLR3: Toll-like receptor 3; TRIF: Toll-IL-1 receptor (TIR)domain-containing adaptor-inducing IFN- $\beta$.

An essential role for TLR3 in protection from herpes simplex virus type 1 (HSV-1) infection has been demonstrated (Zhang et al., 2007). HSV-1 is a prevalent neurotropic virus that infects the central nervous system (CNS) and generates herpes simplex encephalitis (HSE) in children with inborn errors of 
TLR3 immunity (Sancho-Shimizu et al., 2011). The pathogenesis of HSE in children with TLR3-pathway deficiencies is related to impaired TLR3- and Unc-93 homolog B (UNC-93B)-dependent IFN- $\alpha / \beta$ intrinsic immunity against HSV-1 in the CNS (Lafaille et al., 2012). Sato et al. (2018) demonstrated that TLR3 was required for innate immune responses to HSV-1 in neurons and astrocytes. Upon HSV-1 infection, TLR3 recruited the metabolic checkpoint kinase complex mammalian target of rapamycin complex 2 (mTORC2), which led to chemokine induction and TLR3 trafficking to the cell periphery, thus enabling the activation of molecules (including mTORC1) required for type I IFN induction (Mielcarska et al., 2018). In contrast, the failure to express a functional TLR3 disrupted signaling mechanisms that induced antiviral response during infection with HSV-1, indicating that TLR3 is essential for effective antiviral immunity in HSV infection (Mielcarska et al., 2018).

Coxsackievirus strain B serotype 3 (CVB3) is a positive-sense ssRNA virus of the Picornaviridae family (Esfandiarei and McManus, 2008). CVB3 is one of the main causes of myocarditis, and causes a wide range of other infections such as meningitis and pancreatitis (Corsten et al., 2012). It has been reported that TLR3-deficient mice are more susceptible to acute CVB3-induced myocarditis, which is externalized as increased viral load and myocardial tissue damage (Negishi et al., 2008). Abston et al. (2013) revealed that TLR3 prevented the progression from myocarditis to inflammatory dilated cardiomyopathy (iDCM) following CVB3 infection by reducing the IL-4 level and acute viral replication in the heart. Sesti-Costa et al. (2017) found that TLR3 up-regulated CD80 and CD86 in DCs to resist CVB3 infection. In the absence of TLR3, DCs secreted higher levels of the inhibitory molecule programmed death-ligand 1 (PD-L1), while lowering the levels of TNF- $\alpha$ and IL-10 (Sesti-Costa et al., 2017).

The up-regulation of epithelial TLR3 expression during infancy might contribute to age-dependent susceptibility to RV infection (Pott et al., 2012). Jiang et al. (2017) demonstrated that probiotics acted on the TLR3/NF- $\kappa B$ signaling pathway during treatment for diarrhea caused by RV. This not only played a synergistic role with protective factors, but also downregulated the expression of cytokines induced by RV, thus protecting small intestinal epithelial cells and repairing small intestinal injury. Sander et al. (2017) found that prostaglandin E2 (PGE2) directly induced autoimmunity in RV infection and triggered TLR signals, thereby inhibiting viral binding and stimulating viral gene expression.

Based on existing data, it is postulated that TLR3 may contribute to the progression toward the acquired immune deficiency syndrome (AIDS). Myeloid DCs are the primary targets of human immunodeficiency virus 1 (HIV-1) lentiviral transduction following subcutaneous immunization (Martin-Gayo and Yu, 2017). The lentiviral activation of DCs depends on TLR3/7 (Breckpot et al., 2010). Bhargavan et al. (2016) demonstrated that TLR3 activation increased HIV-1 transactivation via the NF- $\mathrm{\kappa B}$ and JNK pathways. Other evidence suggests that selective TLR3 activation promotes the production of type I IFNs, $\beta$-chemokines, and miRNA-155, which preferentially target the 3 ' untranslated region (UTR) of HIV-1 transcript. This significantly decreases HIV-1 infection in macrophages and enhances the development of $\mathrm{HIV}$-specific $\mathrm{CD}^{+}$and $\mathrm{CD}^{+}$cytotoxic $\mathrm{T}$ lymphocytes in humanized mice (Cheng et al., 2018; Nguyen et al., 2020). The gene expression of TLR3 is markedly increased in advanced HIV-1-infected human macrophages, but shows no significant difference in chronic HIV-1-infected and healthy ones (Alvarez-Carbonell et al., 2017; Liu and Gack, 2020). In addition, triggering TLR3 with specific ligands could have therapeutic potential against HIV-1 infection in humans. A combined TLR3 agonist and CD40-targeting HIV-1 vaccine therapy is being established against HIV-1 disease (Cheng et al., 2018; Saxena et al., 2019). The HIV5pep with poly(I:C) vaccination approach was demonstrated to activate the replication of HIV-1 reservoirs and enhance the anti-HIV-1 T-cell response, resulting in reduced HIV-1 pools (Cheng et al., 2018).

Studies have shown that TLR3 is closely related to the current pandemic of coronavirus disease 2019 (COVID-19) caused by a novel virus strain, 2019 novel coronavirus (2019-nCoV)/SARS-CoV-2. SARS-CoV-2 is a positive-sense, ssRNA, $\beta$-coronavirus of the Coronaviridae family, which disrupts the host innate immune response and causes fatal acute respiratory distress syndrome (ARDS) (Guan et al., 2020; $\mathrm{Wu} F$ et al., 2020). An enrichment in rare variants predicted to be loss-of-function (LOF) at the 13 human loci known to govern TLR3- and IRF7-dependent 
type I IFN immunity to influenza virus has been found in patients with lethal COVID-19 relative to those with asymptomatic or benign infection (Zhang et al., 2020). Therefore, TLR3- and IRF7-dependent type I IFN immunity may be essential for preventing life-threatening COVID-19 pneumonia. Furthermore, TLR3 agonists, like chloroquine, can be considered potential drugs for repurposing in COVID-19 treatment (Gao et al., 2020; Prasad et al., 2020). TLR3 is also a critical antigenic receptor for binding newly designed multi-epitope vaccines for COVID-19 (Dong et al., 2020; Ismail et al., 2020).

Hidaka et al. (2006) found a missense mutation (F3035) in the TLR3 gene related to encephalopathy caused by the influenza A virus (IAV). Meng et al. (2016) reported that after IAV infection, mouse mastocytoma cell line (P815) cells mediate hyper-induction of proinflammatory cytokines and chemokines, with TLR3 playing a key role in the expression of proinflammatory cytokines. Huo et al. (2018) showed that, compared with other virus infections and inflammation, the TLR3 signaling pathways are activated preferentially following IAV infection to release a range of proinflammatory cytokines.

Evidence suggests that TLR3 shows both protective and damaging functions in the context of some human viral infections. Hepatitis $\mathrm{C}$ virus ( $\mathrm{HCV}$ ), a ssRNA virus, induces hepatitis $\mathrm{C}$, probably along with developing complications such as cirrhosis, liver failure, and hepatocellular carcinoma (Spearman et al., 2019). Li et al. (2012) reported that TLR3 may contribute to the intrahepatic and unbalanced proinflammatory response. In contrast, a recent report showed that TLR3 activates macrophages to release exosomes that contain anti-HCV microRNA-29 (miR-29) family members, thereby inhibiting HCV replication in Huh7 cells (Zhou et al., 2016). Mosaad et al. (2019) further proved that the heterozygous CT genotype of TLR3 rs3775290 might be a susceptibility risk factor for chronic HCV infection. In contrast, the combination of female CC-AT-GA and the homozygous CC genotypes may be protective.

Hepatitis B virus (HBV) is a prevalent infectious agent which causes impaired liver function in humans (Assar et al., 2012). The role of TLR3 in HBV infection is also bi-directional. It has been reported that TLR3-knockout mice are unable to express IL-8 and other requisite molecules to activate immune responses against HBV (Maire et al., 2008). An et al. (2007) found that patients with chronic HBV infection presented a slower elevation of TLR3 expression than healthy controls. Ondondo et al. (2009) revealed that patients with chronic hepatitis B (CHB) expressed lower TLR3 in monocyte-derived DCs (MoDCs) than normal controls. Based on the above two research findings, impairment of TLR3 expression and function was thought to be a major reason for the persistence of HBV infection (Karimi-Googheri and Arababadi, 2014). Additionally, Tjwa et al. (2012) demonstrated that activation of myeloid DC using TLR3 ligands led to improved natural killer (NK) cell function in CHB infection. Wang $\mathrm{K}$ et al. (2010) found that messenger RNA (mRNA) levels of TLR3 increased in CHB in the active phase, suggesting that TLR3 may play a vital role in starting innate immunity. Nevertheless, recent reports showed that the TLR3 polymorphism rs3775291 was associated with reduced spontaneous hepatitis B surface antigen ( $\mathrm{HBsAg}$ ) seroclearance (SC) of $\mathrm{HBV}$ infection and an increased risk of developing CHB (Geng et al., 2016; Fischer et al., 2018).

WNV is a flavivirus transmitted by mosquitoes, which causes encephalitis, especially in the elderly and immunocompromised individuals (Kramer et al., 2008). WNV non-structural protein 1 (NSI) is a crucial gene required for viral RNA replication and inhibiting TLR3-mediated signal transduction (Wilson et al., 2008). However, data on the role of TLR3 signaling in WNV protection or pathogenesis are controversial. While some studies have suggested that TLR3 serves a protective role against $\mathrm{WNV}$ by restricting $\mathrm{WNV}$ replication in neurons and through its antagonism against NS1 (Daffis et al., 2008; Wilson et al., 2008), others have demonstrated that compared with TLR3deficient mice, the WT mice were less resistant to lethal WNV infection (Wang et al., 2004). Kong et al. (2008) found that during WNV infection, the expression of TLR3 was reduced in macrophages of young donors, but increased in those of the elderly. This change with aging suggested that increased incidence of WNV encephalitis in elderly humans may be linked to increased TLR3 signaling, which may lead to elevated cytokine levels and contribute to the permeability of the blood-brain barrier. Recent research showed that immunization with NS1 might reduce brain inflammation in the context of TLR3 deficiency (Patel et al., 2019). 
The presence of the TLR3 rs5743313/CT polymorphism is closely related to an increased risk of pneumonia in children infected by the pandemic $\mathrm{A} /$ influenza A (H1N1)/2009 influenza virus (Esposito et al., 2012). A recent study showed that $\mathrm{A} / \mathrm{HK} /$ 415742/09 (pandemic H1N1 influenza (pH1N1)) virusinfected TLR $3^{--}$mice did not have better survival than pH1N1-infected WT mice and showed no difference in viral titer and leukocyte infiltration in the lungs, suggesting that TLR3 did not worsen the pathogenesis of pH1N1 infection (Leung et al., 2014). The precise role of TLR3 against influenza in humans remains to be determined.

The effect of TLR3 on susceptibility to tick-borne encephalitis virus (TBEV) infection is poorly understood. Research by Kindberg et al. (2011) showed that the WT rs3775291 TLR3 allele was more common among TBEV patients than in healthy controls, suggesting that TLR3 might be a risk factor for TBEV infection. It was recently reported that polymorphisms in TLR3 have a statistically significant impact on TBEV infection (Mickienè et al., 2014).

\section{Conclusions and future directions}

In this review, we discussed the TLR3-mediated antiviral response based on the activation and regulation of the TRIF signaling pathway. The TRIF and TRIF-mediated signaling pathways are critical for understanding the role of TLR3 in the immune response, which could give us a new direction to clarify the pathogenesis of diseases and find cures. Significant progress has been made in dissecting the mechanisms of TRIF-dependent activation of IRF3 and NF- $\kappa B$, but how the TRIF/AP-1 pathway works needs further study. Recent work has focused on proteins that act as adaptors or mediate the activation of adaptors on the TRIF pathway, but some of their mechanisms remain to be further determined. A variety of enzymes that act as negative regulatory agencies of TLR 3 have been found, but how these regulators are activated during viral infection and their cell type- and speciesspecific roles remain unclear.

Moreover, the dual role of TLR3 in ensuring or compromising host immunity against viruses is still largely unknown. In the case of chronic RNA viral infections that lead to sustained IFN- $\alpha / \beta$ signaling, the
TLR3-TRIF axis may be crucial in determining how the balance between antiviral and immune regulatory pathways affects defensive versus offensive responses. In future work, the TLR3-TRIF pathway may be essential for the establishment of specific therapeutic approaches to diminish TLR3-driven disease.

\section{Acknowledgments}

This work was supported by the National Key R\&D Program of China (No. 2018YFD0501705), the Chongqing Basic Research Program (No. cstc2018jcyjAX0615), and the Fundamental Research Funds for the Central Universities (Nos. XDJK2018C059 and XDJK2018C060), China. We thank LetPub (http://www.letpub.com) for its linguistic assistance and scientific consultation during the preparation of this manuscript.

\section{Author contributions}

Huashan YI, Yujuan CHEN, and Xianping MA were responsible for conceptualization; Yujuan CHEN, Junhong LIN, and Yao ZHAO for article writing, data collection, and manuscript revision; Yujuan CHEN for picture design; and Xianping MA and Huashan YI for supervision. All authors have read and approved the final manuscript.

\section{Compliance with ethics guidelines}

Yujuan CHEN, Junhong LIN, Yao ZHAO, Xianping MA, and Huashan YI declare that they have no conflict of interest.

This article does not contain any studies with human or animal subjects performed by any of the authors.

\section{References}

Abston ED, Coronado MJ, Bucek A, et al., 2013. TLR3 deficiency induces chronic inflammatory cardiomyopathy in resistant mice following coxsackievirus B3 infection: role for IL-4. Am J Phys Regul Integr Comp Phys, 304(4): R267-R277.

https://doi.org/10.1152/ajpregu.00516.2011

Agier J, Żelechowska P, Kozłowska E, et al., 2016. Expression of surface and intracellular Toll-like receptors by mature mast cells. Cent Eur J Immunol, 41(4):333-338. https://doi.org/10.5114/ceji.2016.65131

Alexopoulou L, Holt AC, Medzhitov R, et al., 2001. Recognition of double-stranded RNA and activation of NF- $\mathrm{kB}$ by Toll-like receptor 3. Nature, 413(6857):732-738. https://doi.org/10.1038/35099560

Alvarez-Carbonell D, Garcia-Mesa Y, Milne S, et al., 2017. Toll-like receptor 3 activation selectively reverses HIV latency in microglial cells. Retrovirology, 14:9. https://doi.org/10.1186/s12977-017-0335-8

Ameyar M, Wisniewska M, Weitzman JB, 2003. A role for AP-1 in apoptosis: the case for and against. Biochimie, 85(8):747-752. https://doi.org/10.1016/j.biochi.2003.09.006

An BY, Xie Q, Lin LY, et al., 2007. Expression of Toll-like 
receptor 3 on peripheral blood dendritic cells in $\mathrm{HBeAg}$ positive patients with chronic hepatitis B. Chin J Hepatol, 15(10):729-733 (in Chinese). https://doi.org/10.3760/j.issn:1007-3418.2007.10.003

Antosz H, Choroszyńska D, 2013. Negative regulation of Toll-like receptor signalling. Postepy Hig Med Dosw, 67: 339-350.

https://doi.org/10.5604/17322693.1046538

Assar S, Arababadi MK, Ahmadabadi BN, et al., 2012. Occult hepatitis B virus (HBV) infection: a global challenge for medicine. Clin Lab, 58(11-12):1225-1230.

Baratchian M, Davis CA, Shimizu A, et al., 2016. Distinct activation mechanisms of NF- $\kappa B$ regulator inhibitor of $\mathrm{NF}-\kappa \mathrm{B}$ kinase (IKK) by isoforms of the cell death regulator cellular FLICE-like inhibitory protein (cFLIP). J Biol Chem, 291(14):7608-7620. https://doi.org/10.1074/jbc.M116.718122

Barton GM, Kagan JC, 2009. A cell biological view of Tolllike receptor function: regulation through compartmentalization. Nat Rev Immunol, 9(8):535-542.

https://doi.org/10.1038/nri2587

Bhargavan B, Woollard SM, Kanmogne GD, 2016. Toll-like receptor-3 mediates HIV-1 transactivation via NFKB and JNK pathways and histone acetylation, but prolonged activation suppresses Tat and HIV-1 replication. Cell Signal, 28(2):7-22.

https://doi.org/10.1016/j.cellsig.2015.11.005

Blasius AL, Beutler B, 2010. Intracellular Toll-like receptors. Immunity, 32(3):305-315. https://doi.org/10.1016/j.immuni.2010.03.012

Boone DL, Turer EE, Lee EG, et al., 2004. The ubiquitinmodifying enzyme A20 is required for termination of Toll-like receptor responses. Nat Immunol, 5(10):10521060 . https://doi.org/10.1038/ni1110

Botos I, Liu L, Wang Y, et al., 2009. The Toll-like receptor 3: dsRNA signaling complex. Biochim Biophys Acta Gene Regul Mech, 1789(9-10):667-674. https://doi.org/10.1016/j.bbagrm.2009.06.005

Breckpot K, Escors D, Arce F, et al., 2010. HIV-1 lentiviral vector immunogenicity is mediated by Toll-like receptor 3 (TLR3) and TLR7. J Virol, 84(11):5627-5636. https://doi.org/10.1128/jvi.00014-10

Bugge M, Bergstrom B, Eide OK, et al., 2017. Surface Tolllike receptor 3 expression in metastatic intestinal epithelial cells induces inflammatory cytokine production and promotes invasiveness. J Biol Chem, 292(37):1540815425. https://doi.org/10.1074/jbc.M117.784090

Cao LL, Liu SD, Li YF, et al., 2019. The nuclear matrix protein SAFA surveils viral RNA and facilitates immunity by activating antiviral enhancers and super-enhancers. Cell Host Microbe, 26(3):369-384.e8. https://doi.org/10.1016/j.chom.2019.08.010

Cao Y, Sun Y, Chang HY, et al., 2019. The E3 ubiquitin ligase RNF182 inhibits TLR-triggered cytokine production through promoting p65 ubiquitination and degradation. FEBS Lett, 593(22):3210-3219. https://doi.org/10.1002/1873-3468.13583

Cartwright T, Perkins ND, Wilson CL, 2016. NFKB1: a suppressor of inflammation, ageing and cancer. FEBS $J$, 283(10):1812-1822.

https://doi.org/10.1111/febs.13627

Carty M, Bowie AG, 2019. SARM: from immune regulator to cell executioner. Biochem Pharmacol, 161:52-62. https://doi.org/10.1016/j.bcp.2019.01.005

Chen CY, Shih YC, Hung YF, et al., 2019. Beyond defense: regulation of neuronal morphogenesis and brain functions via Toll-like receptors. J Biomed Sci, 26:90. https://doi.org/10.1186/s12929-019-0584-z

Chen HW, Yang YK, Xu H, et al., 2015. Ring finger protein 166 potentiates RNA virus-induced interferon- $\beta$ production via enhancing the ubiquitination of TRAF3 and TRAF6. Sci Rep, 5:14770. https://doi.org/10.1038/srep14770

Cheng L, Wang Q, Li GM, et al., 2018. TLR3 agonist and CD40-targeting vaccination induces immune responses and reduces HIV-1 reservoirs. J Clin Invest, 128(10): 4387-4396. https://doi.org/10.1172/jci99005

Choe J, Kelker MS, Wilson IA, 2005. Crystal structure of human Toll-like receptor 3 (TLR3) ectodomain. Science, 309(5734):581-585. https://doi.org/10.1126/science. 1115253

Corcoran SE, O'Neill LAJ, 2016. HIF1 $\alpha$ and metabolic reprogramming in inflammation. J Clin Invest, 126(10):36993707. https://doi.org/10.1172/jci84431

Corsten MF, Schroen B, Heymans S, 2012. Inflammation in viral myocarditis: friend or foe? Trends $\mathrm{Mol} \mathrm{Med,} \mathrm{18(7):}$ 426-437. https://doi.org/10.1016/j.molmed.2012.05.005

Cui J, Li YY, Zhu L, et al., 2012. NLRP4 negatively regulates type I interferon signaling by targeting the kinase TBK1 for degradation via the ubiquitin ligase DTX4. Nat Immunol, 13(4):387-395. https://doi.org/10.1038/ni.2239

Daffis S, Samuel MA, Suthar MS, et al., 2008. Toll-like receptor 3 has a protective role against West Nile virus infection. J Virol, 82(21):10349-10358. https://doi.org/10.1128/jvi.00935-08

Diehl GE, Yue HH, Hsieh K, et al., 2004. TRAIL-R as a negative regulator of innate immune cell responses. Immunity, 21(6):877-889. https://doi.org/10.1016/j.immuni.2004.11.008

Dong R, Chu ZG, Yu FX, et al., 2020. Contriving multi-epitope subunit of vaccine for COVID-19: immunoinformatics approaches. Front Immunol, 11:1784. https://doi.org/10.3389/fimmu.2020.01784

Doyle M, Jantsch MF, 2002. New and old roles of the doublestranded RNA-binding domain. J Struct Biol, 140(1-3): 147-153. https://doi.org/10.1016/s1047-8477(02)00544-0

Emmerich CH, Ordureau A, Strickson S, et al., 2013. Activation of the canonical IKK complex by K63/M1-linked hybrid ubiquitin chains. Proc Natl Acad Sci USA, 110(38): 
$15247-15252$

https://doi.org/10.1073/pnas.1314715110

Ermolaeva MA, Michallet MC, Papadopoulou N, et al., 2008. Function of TRADD in tumor necrosis factor receptor 1 signaling and in TRIF-dependent inflammatory responses. Nat Immunol, 9(9):1037-1046. https://doi.org/10.1038/ni.1638

Esfandiarei M, McManus BM, 2008. Molecular biology and pathogenesis of viral myocarditis. Annu Rev Pathol Mech Dis, 3:127-155.

https://doi.org/10.1146/annurev.pathmechdis.3.121806.151534

Esposito S, Molteni CG, Giliani S, et al., 2012. Toll-like receptor 3 gene polymorphisms and severity of pandemic A/H1N1/2009 influenza in otherwise healthy children. Virol J, 9:270. https://doi.org/10.1186/1743-422x-9-270

Ewald SE, Engel A, Lee J, et al., 2011. Nucleic acid recognition by Toll-like receptors is coupled to stepwise processing by cathepsins and asparagine endopeptidase. $J$ Exp Med, 208(4):643-651.

https://doi.org/10.1084/jem.20100682

Fang F, Ooka K, Sun XY, et al., 2013. A synthetic TLR3 ligand mitigates profibrotic fibroblast responses by inducing autocrine IFN signaling. J Immunol, 191(6):29562966. https://doi.org/10.4049/jimmunol.1300376

Fischer J, Koukoulioti E, Schott E, et al., 2018. Polymorphisms in the Toll-like receptor 3 (TLR3) gene are associated with the natural course of hepatitis B virus infection in caucasian population. Sci Rep, 8:12737. https://doi.org/10.1038/s41598-018-31065-6

Fitzgerald KA, Kagan JC, 2020. Toll-like receptors and the control of immunity. Cell, 180(6):1044-1066. https://doi.org/10.1016/j.cell.2020.02.041

Freedman NJ, Shenoy SK, 2018. Regulation of inflammation by $\beta$-arrestins: not just receptor tales. Cell Signal, 41:4145 . https://doi.org/10.1016/j.cellsig.2017.02.008

Frobøse H, Rønn SG, Heding PE, et al., 2006. Suppressor of cytokine signaling-3 inhibits interleukin-1 signaling by targeting the TRAF-6/TAK1 complex. Mol Endocrinol, 20(7):1587-1596. https://doi.org/10.1210/me.2005-0301

Funami K, Matsumoto M, Oshiumi H, et al., 2004. The cytoplasmic 'linker region' in Toll-like receptor 3 controls receptor localization and signaling. Int Immunol, 16(8): 1143-1154. https://doi.org/10.1093/intimm/dxh115

Funami K, Sasai M, Ohba Y, et al., 2007. Spatiotemporal mobilization of Toll/IL-1 receptor domain-containing adaptor molecule-1 in response to dsRNA. J Immunol, 179(10):6867-6872. https://doi.org/10.4049/jimmunol.179.10.6867

Funami K, Sasai M, Oshiumi H, et al., 2008. Homooligomerization is essential for Toll/interleukin-1 receptor domain-containing adaptor molecule-1-mediated NF- $\kappa \mathrm{B}$ and interferon regulatory factor-3 activation. $J$ Biol Chem, 283(26):18283-18291.
https://doi.org/10.1074/jbc.M801013200

Funami K, Matsumoto M, Obuse C, et al., 2016. 14-3-3- $\zeta$ participates in TLR3-mediated TICAM-1 signal-platform formation. Mol Immunol, 73:60-68.

https://doi.org/10.1016/j.molimm.2016.03.010

Galluzzi L, Green DR, 2019. Autophagy-independent functions of the autophagy machinery. Cell, 177(7):16821699.

https://doi.org/10.1016/j.cell.2019.05.026

Gao D, Wang XD, Jin GY, et al., 2015. Research progress of Toll-like receptor and ligand complex structure. China $J$ Cell Mol Immunol, 31(4):553-556 (in Chinese). https://doi.org/10.13423/j.cnki.cjcmi.007335

Gao JJ, Tian ZX, Yang X, 2020. Breakthrough: chloroquine phosphate has shown apparent efficacy in treatment of COVID-19 associated pneumonia in clinical studies. Biosci Trends, 14(1):72-73. https://doi.org/10.5582/bst.2020.01047

Geng PL, Song LX, An HJ, et al., 2016. Toll-like receptor 3 is associated with the risk of HCV infection and HBV-related diseases. Medicine (Baltimore), 95(21):e2302. https://doi.org/10.1097/md.0000000000002302

Gong T, Liu L, Jiang W, et al., 2020. DAMP-sensing receptors in sterile inflammation and inflammatory diseases. Nat Rev Immunol, 20(2):95-112. https://doi.org/10.1038/s41577-019-0215-7

Gosu V, Son S, Shin D, et al., 2019. Insights into the dynamic nature of the dsRNA-bound TLR3 complex. Sci Rep, 9:3652. https://doi.org/10.1038/s41598-019-39984-8

Gowen BB, Hoopes JD, Wong MH, et al., 2006. TLR3 deletion limits mortality and disease severity due to phlebovirus infection. J Immunol, 177(9):6301-6307. https://doi.org/10.4049/jimmunol.177.9.6301

Guan WJ, Ni ZY, Hu Y, et al., 2020. Clinical characteristics of coronavirus disease 2019 in China. N Engl J Med, 382(18):1708-1720.

https://doi.org/10.1056/NEJMoa2002032

Guo BC, Cheng GH, 2007. Modulation of the interferon antiviral response by the TBK1/IKKI adaptor protein TANK. J Biol Chem, 282(16):11817-11826. https://doi.org/10.1074/jbc.M700017200

Han CF, Jin J, Xu S, et al., 2010. Integrin CD11b negatively regulates TLR-triggered inflammatory responses by activating Syk and promoting degradation of MyD88 and TRIF via Cbl-b. Nat Immunol, 11(8):734-742. https://doi.org/10.1038/ni.1908

Hardarson HS, Baker JS, Yang Z, et al., 2007. Toll-like receptor 3 is an essential component of the innate stress response in virus-induced cardiac injury. Am J Physiol Heart Circ Physiol, 292(1):H251-H258. https://doi.org/10.1152/ajpheart.00398.2006

Hase K, Contu VR, Kabuta C, et al., 2020. Cytosolic domain of SIDT2 carries an arginine-rich motif that binds to RNA/DNA and is important for the direct transport of nucleic acids into lysosomes. Autophagy, 16(11):1974-1988. https://doi.org/10.1080/15548627.2020.1712109

He X, Li Y, Li C, et al., 2013. USP2a negatively regulates 
IL-1 $\beta$ - and virus-induced NF- $\kappa \mathrm{B}$ activation by deubiquitinating TRAF6. J Mol Cell Biol, 5(1):39-47. https://doi.org/10.1093/jmcb/mjs024

Hidaka F, Matsuo S, Muta T, et al., 2006. A missense mutation of the Toll-like receptor 3 gene in a patient with influenza-associated encephalopathy. Clin Immunol, 119(2): 188-194. https://doi.org/10.1016/j.clim.2006.01.005

Honda K, Takaoka A, Taniguchi T, 2006. Type I inteferon gene induction by the interferon regulatory factor family of transcription factors. Immunity, 25(3):349-360. https://doi.org/10.1016/j.immuni.2006.08.009

$\mathrm{Hu}$ YH, Zhang Y, Jiang LQ, et al., 2015. WDFY1 mediates TLR3/4 signaling by recruiting TRIF. EMBO Rep, 16(4): 447-455. https://doi.org/10.15252/embr.201439637

Huh HD, Lee E, Shin J, et al., 2017. STRAP positively regulates TLR3-triggered signaling pathway. Cell Immunol, 318:55-60. https://doi.org/10.1016/j.cellimm.2017.06.005

Huo CY, Jin Y, Zou SM, et al., 2018. Lethal influenza A virus preferentially activates TLR3 and triggers a severe inflammatory response. Virus Res, 257:102-112. https://doi.org/10.1016/j.virusres.2018.09.012

Ismail S, Ahmad S, Azam SS, 2020. Immunoinformatics characterization of SARS-CoV-2 spike glycoprotein for prioritization of epitope based multivalent peptide vaccine. J Mol Liq, 314:113612 https://doi.org/10.1016/j.molliq.2020.113612

Itoh K, Watanabe A, Funami K, et al., 2008. The clathrinmediated endocytic pathway participates in dsRNAinduced IFN- $\beta$ production. J Immunol, 181(8):5522-5529. https://doi.org/10.4049/jimmunol.181.8.5522

Jiang Y, Ye L, Cui Y, et al., 2017. Effects of Lactobacillus rhamnosus GG on the maturation and differentiation of dendritic cells in rotavirus-infected mice. Benef Microbes, 8(4):645-656. https://doi.org/10.3920/bm2016.0157

Johnsen IB, Nguyen TT, Ringdal M, et al., 2006. Toll-like receptor 3 associates with c-Src tyrosine kinase on endosomes to initiate antiviral signaling. EMBO J, 25(14): 3335-3346. https://doi.org/10.1038/sj.emboj.7601222

Kang JY, Lee JO, 2011. Structural biology of the Toll-like receptor family. Annu Rev Biochem, 80:917-941. https://doi.org/10.1146/annurev-biochem-052909-141507

Karikó K, Bhuyan P, Capodici J, et al., 2004. Small interfering RNAs mediate sequence-independent gene suppression and induce immune activation by signaling through Tolllike receptor 3. J Immunol, 172(11):6545-6549. https://doi.org/10.4049/jimmunol.172.11.6545

Karikó K, Buckstein M, Ni H, et al., 2005. Suppression of RNA recognition by Toll-like receptors: the impact of nucleoside modification and the evolutionary origin of RNA. Immunity, 23(2):165-175. https://doi.org/10.1016/j.immuni.2005.06.008

Karimi-Googheri M, Arababadi MK, 2014. TLR3 plays significant roles against hepatitis B virus. Mol Biol Rep,
41(5):3279-3286.

https://doi.org/10.1007/s11033-014-3190-x

Kawai T, Akira S, 2007. Signaling to NF- $\kappa$ B by Toll-like receptors. Trends Mol Med, 13(11):460-469. https://doi.org/10.1016/j.molmed.2007.09.002

Kawai T, Akira S, 2010. The role of pattern-recognition receptors in innate immunity: update on Toll-like receptors. Nat Immunol, 11(5):373-384. https://doi.org/10.1038/ni.1863

Kawasaki T, Kawai T, 2014. Toll-like receptor signaling pathways. Front Immunol, 5:461. https://doi.org/10.3389/fimmu.2014.00461

Kayagaki N, Phung Q, Chan S, et al., 2007. A deubiquitinase that regulates type I interferon production. Science, 318(5856):1628-1632. https://doi.org/10.1126/science. 1145918

Kindberg E, Vene S, Mickiene A, et al., 2011. A functional Toll-like receptor 3 gene (TLR3) may be a risk factor for tick-borne encephalitis virus (TBEV) infection. $J$ Infect Dis, 203(4):523-528.

https://doi.org/10.1093/infdis/jiq082

Kleinman ME, Yamada K, Takeda A, et al., 2008. Sequenceand target-independent angiogenesis suppression by siRNA via TLR3. Nature, 452(7187):591-597. https://doi.org/10.1038/nature06765

Kohl B, Granitzka V, Singh A, et al., 2019. Comparison of backbone dynamics of the $\mathrm{p} 50$ dimerization domain of $\mathrm{NF \kappa B}$ in the homodimeric transcription factor NFKB1 and in its heterodimeric complex with RelA (p65). Protein Sci, 28(12):2064-2072. https://doi.org/10.1002/pro.3736

Kong KF, Delroux K, Wang XM, et al., 2008. Dysregulation of TLR3 impairs the innate immune response to West Nile virus in the elderly. $J$ Virol, 82(15):7613-7623. https://doi.org/10.1128/jvi.00618-08

Kramer LD, Styer LM, Ebel GD, 2008. A global perspective on the epidemiology of West Nile virus. Annu Rev Entomol, 53:61-81. https://doi.org/10.1146/annurev.ento.53.103106.093258

Kulka M, Alexopoulou L, Flavell RA, et al., 2004. Activation of mast cells by double-stranded RNA: evidence for activation through Toll-like receptor 3. J Allergy Clin Immunol, 114(1):174-182. https://doi.org/10.1016/j.jaci.2004.03.049

Kumeta H, Sakakibara H, Enokizono Y, et al., 2014. The Nterminal domain of TIR domain-containing adaptor molecule-1, TICAM-1. J Biomol NMR, 58(3):227-230. https://doi.org/10.1007/s10858-014-9819-1

Lafaille FG, Pessach IM, Zhang SY, et al., 2012. Impaired intrinsic immunity to HSV-1 in human iPSC-derived TLR3-deficient CNS cells. Nature, 491(7426):769-773. https://doi.org/10.1038/nature11583

Langston PK, Nambu A, Jung J, et al., 2019. Glycerol phosphate shuttle enzyme GPD2 regulates macrophage inflammatory responses. Nat Immunol, 20(9):1186-1195. https://doi.org/10.1038/s41590-019-0453-7

Laporte SA, Scott MGH, 2019. $\beta$-Arrestins: multitask scaffolds orchestrating the where and when in cell signalling. In: 
Scott MGH, Laporte SA (Eds.), Beta-Arrestins. Humana Press, New York, p.9-55. https://doi.org/10.1007/978-1-4939-9158-7_2

Lee HK, Dunzendorfer S, Soldau K, et al., 2006. Doublestranded RNA-mediated TLR3 activation is enhanced by CD14. Immunity, 24(2):153-163. https://doi.org/10.1016/j.immuni.2005.12.012

Lee KG, Xu SL, Kang ZH, et al., 2012. Bruton's tyrosine kinase phosphorylates Toll-like receptor 3 to initiate antiviral response. Proc Natl Acad Sci USA, 109(15):57915796. https://doi.org/10.1073/pnas.1119238109

Lei CQ, Wu X, Zhong X, et al., 2019. USP19 inhibits TNF- $\alpha$ and IL-1 $\beta$-triggered NF- $\kappa \mathrm{B}$ activation by deubiquitinating TAK1. J Immunol, 203(1):259-268. https://doi.org/10.4049/jimmunol.1900083

Leonard JN, Ghirlando R, Askins J, et al., 2008. The TLR3 signaling complex forms by cooperative receptor dimerization. Proc Natl Acad Sci USA, 105(1):258-263. https://doi.org/10.1073/pnas.0710779105

Leung YHC, Nicholls JM, Ho CK, et al., 2014. Highly pathogenic avian influenza A H5N1 and pandemic H1N1 virus infections have different phenotypes in Toll-like receptor 3 knockout mice. J Gen Virol, 95(Pt 9):1870-1879. https://doi.org/10.1099/vir.0.066258-0

Li FB, Li Y, Liang HC, et al., 2018. HECTD3 mediates TRAF3 polyubiquitination and type I interferon induction during bacterial infection. J Clin Invest, 128(9): 4148-4162. https://doi.org/10.1172/jci120406

Li K, Li NL, Wei D, et al., 2012. Activation of chemokine and inflammatory cytokine response in hepatitis $\mathrm{C}$ virusinfected hepatocytes depends on Toll-like receptor 3 sensing of hepatitis C virus double-stranded RNA intermediates. Hepatology, 55(3):666-675. https://doi.org/10.1002/hep.24763

Li ST, Wang LY, Berman M, et al., 2011. Mapping a dynamic innate immunity protein interaction network regulating type I interferon production. Immunity, 35(3):426-440. https://doi.org/10.1016/j.immuni.2011.06.014

Li WW, Nie Y, Yang Y, et al., 2020. Ubiquitination of TLR3 by TRIM3 signals its ESCRT-mediated trafficking to the endolysosomes for innate antiviral response. Proc Natl Acad Sci USA, 117(38):23707-23716. https://doi.org/10.1073/pnas.2002472117

Limmon GV, Arredouani M, McCann KL, et al., 2008. Scavenger receptor class-A is a novel cell surface receptor for double-stranded RNA. FASEB J, 22(1):159-167. https://doi.org/10.1096/fj.07-8348com

Liu GK, 2019. The Effect of Ubiquitin Ligase Nedd4l on Tolllike Receptor Signaling Transduction of Macrophage. $\mathrm{PhD}$ Dissemination, the Second Military Medical University, Shanghai, China (in Chinese).

Liu GQ, Gack MU, 2020. Distinct and orchestrated functions of RNA sensors in innate immunity. Immunity, 53(1):26-42. https://doi.org/10.1016/j.immuni.2020.03.017

Liu GQ, Lu Y, Thulasi Raman SN, et al., 2018. Nuclearresident RIG-I senses viral replication inducing antiviral immunity. Nat Commun, 9:3199.

https://doi.org/10.1038/s41467-018-05745-w

Liu L, Botos I, Wang Y, et al., 2008. Structural basis of Tolllike receptor 3 signaling with double-stranded RNA. Science, 320(5874):379-381. https://doi.org/10.1126/science.1155406

Liu SQ, Cai X, Wu JX, et al., 2015. Phosphorylation of innate immune adaptor proteins MAVS, STING, and TRIF induces IRF3 activation. Science, 347(6227):aaa2630. https://doi.org/10.1126/science.aaa2630

Loo YM, Gale M, 2011. Immune signaling by RIG-I-like receptors. Immunity, 34(5):680-692. https://doi.org/10.1016/j.immuni.2011.05.003

Lu D, Song J, Sun YZ, et al., 2018. Mutations of deubiquitinase OTUD1 are associated with autoimmune disorders. J Autoimmun, 94:156-165. https://doi.org/10.1016/j.jaut.2018.07.019

Luo JQ, Obmolova G, Malia TJ, et al., 2012. Lateral clustering of TLR3: dsRNA signaling units revealed by TLR3ecd: 3 fabs quaternary structure. J Mol Biol, 421(1):112-124. https://doi.org/10.1016/j.jmb.2012.05.006

Luo L, Curson JEB, Liu LP, et al., 2020. SCIMP is a universal Toll-like receptor adaptor in macrophages. J Leukoc Biol, 107(2):251-262. https://doi.org/10.1002/jlb.2ma0819-138rr

Mahita J, Sowdhamini R, 2017. Integrative modelling of TIR domain-containing adaptor molecule inducing interferon- $\beta$ (TRIF) provides insights into its autoinhibited state. Biol Direct, 12:9. https://doi.org/10.1186/s13062-017-0179-0

Mahita J, Sowdhamini R, 2018. Investigating the effect of key mutations on the conformational dynamics of Tolllike receptor dimers through molecular dynamics simulations and protein structure networks. Proteins, 86(4):475490. https://doi.org/10.1002/prot.25467

Maire M, Parent R, Morand AL, et al., 2008. Characterization of the double-stranded RNA responses in human liver progenitor cells. Biochem Biophys Res Commun, 368(3): 556-562. https://doi.org/10.1016/j.bbrc.2008.01.123

Marshall JS, Portales-Cervantes L, Leong E, 2019. Mast cell responses to viruses and pathogen products. Int $J \mathrm{Mol}$ Sci, 20(17):4241. https://doi.org/10.3390/ijms20174241

Martin-Gayo E, Yu XG, 2017. Dendritic cell immune responses in HIV-1 controllers. Curr HIV/AIDS Rep, 14(1):1-7. https://doi.org/10.1007/s11904-017-0345-0

Matsumoto M, Funami K, Tanabe M, et al., 2003. Subcellular localization of Toll-like receptor 3 in human dendritic cells. J Immunol, 171(6):3154-3162. https://doi.org/10.4049/jimmunol.171.6.3154

Matsumoto M, Oshiumi H, Seya T, 2011. Antiviral responses induced by the TLR3 pathway. Rev Med Virol, 21(2):67-77. https://doi.org/10.1002/rmv.680

Matsumoto M, Takeda Y, Seya T, 2020. Targeting Toll-like receptor 3 in dendritic cells for cancer immunotherapy. Expert Opin Biol Ther, 20(8):937-946. 
https://doi.org/10.1080/14712598.2020.1749260

Meng D, Huo CY, Wang M, et al., 2016. Influenza a viruses replicate productively in mouse mastocytoma cells (P815) and trigger pro-inflammatory cytokine and chemokine production through TLR3 signaling pathway. Front Microbiol, 7:2130. https://doi.org/10.3389/fmicb.2016.02130

Meylan E, Burns K, Hofmann K, et al., 2004. RIP1 is an essential mediator of Toll-like receptor 3-induced NF- $\mathrm{KB}$ activation. Nat Immunol, 5(5):503-507. https://doi.org/10.1038/ni1061

Mickienè A, Pakalnienè J, Nordgren J, et al., 2014. Polymorphisms in chemokine receptor 5 and Toll-like receptor 3 genes are risk factors for clinical tick-borne encephalitis in the Lithuanian population. PLoS ONE, 9(9):e106798. https://doi.org/10.1371/journal.pone.0106798

Mielcarska MB, Bossowska-Nowicka M, Toka FN, 2018. Functional failure of TLR3 and its signaling components contribute to herpes simplex encephalitis. J Neuroimmunol, 316:65-73.

https://doi.org/10.1016/j.jneuroim.2017.12.011

Mineev KS, Goncharuk SA, Arseniev AS, 2014. Toll-like receptor 3 transmembrane domain is able to perform various homotypic interactions: an NMR structural study. FEBS Lett, 588(21):3802-3807. https://doi.org/10.1016/j.febslet.2014.08.031

Mitchell S, Vargas J, Hoffmann A, 2016. Signaling via the NFkB system. WIREs Syst Biol Med, 8(3):227-241. https://doi.org/10.1002/wsbm.1331

Mortaz E, Adcock IM, Abedini A, et al., 2017. The role of pattern recognition receptors in lung sarcoidosis. Eur $J$ Pharmacol, 808:44-48. https://doi.org/10.1016/j.ejphar.2017.01.020

Mosaad YM, Metwally SS, Farag RE, et al., 2019. Association between Toll-like receptor 3 (TLR3) rs3775290, TLR7 rs179008, TLR9 rs352140 and chronic HCV. Immunol Invest, 48(3):321-332. https://doi.org/10.1080/08820139.2018.1527851

Negishi H, Osawa T, Ogami K, et al., 2008. A critical link between Toll-like receptor 3 and type II interferon signaling pathways in antiviral innate immunity. Proc Natl Acad Sci USA, 105(51):20446-20451. https://doi.org/10.1073/pnas.0810372105

Nguyen H, Gazy N, Venketaraman V, 2020. A role of intracellular Toll-like receptors $(3,7$, and 9$)$ in response to Mycobacterium tuberculosis and co-infection with HIV. Int J Mol Sci, 21(17):6148. https://doi.org/10.3390/ijms21176148

Nguyen VP, Chen J, Petrus MN, et al., 2014. A new domain in the Toll/IL-1R domain-containing adaptor inducing interferon- $\beta$ factor protein amino terminus is important for tumor necrosis factor- $\alpha$ receptor-associated factor 3 association, protein stabilization and interferon signaling. J Innate Immun, 6(3):377-393. https://doi.org/10.1159/000356408

Ondondo BO, Brunham RC, Harrison WG, et al., 2009. Frequency and magnitude of Chlamydia trachomatis elementary body- and heat shock protein 60 -stimulated interferon $\gamma$ responses in peripheral blood mononuclear cells and endometrial biopsy samples from women with high exposure to infection. $J$ Infect Dis, 199(12):17711779.

https://doi.org/10.1086/599095

Oshiumi H, Matsumoto M, Funami K, et al., 2003. TICAM-1, an adaptor molecule that participates in Toll-like receptor 3 -mediated interferon- $\beta$ induction. Nat Immunol, 4(2): 161-167. https://doi.org/10.1038/ni886

Oshiumi H, Okamoto M, Fujii K, et al., 2011. The TLR3/ TICAM-1 pathway is mandatory for innate immune responses to poliovirus infection. J Immunol, 187(10): 5320-5327. https://doi.org/10.4049/jimmunol.1101503

Pabo CO, Sauer RT, 1984. Protein-DNA recognition. Annu Rev Biochem, 53:293-321. https://doi.org/10.1146/annurev.bi.53.070184.001453

Park GB, Hur DY, Kim YS, et al., 2015. TLR3/TRIF signalling pathway regulates IL-32 and IFN- $\beta$ secretion through activation of RIP-1 and TRAF in the human cornea. $J$ Cell Mol Med, 19(5):1042-1054. https://doi.org/10.1111/jcmm.12495

Patel S, Sinigaglia A, Barzon L, et al., 2019. Role of NS1 and TLR3 in pathogenesis and immunity of WNV. Viruses, 11(7):603. https://doi.org/10.3390/v11070603

Patra MC, Batool M, Haseeb M, et al., 2020. A computational probe into the structure and dynamics of the full-length Toll-like receptor 3 in a phospholipid bilayer. Int $\mathrm{J} \mathrm{Mol}$ Sci, 21(8):2857. https://doi.org/10.3390/ijms21082857

Peisley A, Hur S, 2013. Multi-level regulation of cellular recognition of viral dsRNA. Cell Mol Life Sci, 70(11): 1949-1963. https://doi.org/10.1007/s00018-012-1149-4

Pelka K, Bertheloot D, Reimer E, et al., 2018. The chaperone UNC93B1 regulates Toll-like receptor stability independently of endosomal TLR transport. Immunity, 48(5): 911-922.e7. https://doi.org/10.1016/j.immuni.2018.04.011

Peng J, Yuan Q, Lin B, et al., 2010. SARM inhibits both TRIF- and MyD88-mediated AP-1 activation. Eur $J$ Immunol, 40(6):1738-1747. https://doi.org/10.1002/eji.200940034

Perales-Linares R, Navas-Martin S, 2013. Toll-like receptor 3 in viral pathogenesis: friend or foe? Immunology, 140(2): 153-167. https://doi.org/10.1111/imm.12143

Piliponsky AM, Romani L, 2018. The contribution of mast cells to bacterial and fungal infection immunity. Immunol Rev, 282(1):188-197. https://doi.org/10.1111/imr.12623

Pott J, Stockinger S, Torow N, et al., 2012. Age-dependent TLR3 expression of the intestinal epithelium contributes to rotavirus susceptibility. PLoS Pathog, 8(5):e1002670. https://doi.org/10.1371/journal.ppat.1002670

Prasad K, Khatoon F, Rashid S, et al., 2020. Targeting hub 
genes and pathways of innate immune response in COVID19: a network biology perspective. Int J Biol Macromol, $163: 1-8$

https://doi.org/10.1016/j.ijbiomac.2020.06.228

Rai RC, 2020. Host inflammatory responses to intracellular invaders: review study. Life Sci, 240:117084. https://doi.org/10.1016/j.lfs.2019.117084

Rehwinkel J, Gack MU, 2020. RIG-I-like receptors: their regulation and roles in RNA sensing. Nat Rev Immunol, 20(9): 537-551. https://doi.org/10.1038/s41577-020-0288-3

Ryo A, Suizu F, Yoshida Y, et al., 2003. Regulation of NF- $\kappa B$ signaling by Pin1-dependent prolyl isomerization and ubiquitin-mediated proteolysis of p65/Rela. Mol Cell, 12(6):1413-1426 https://doi.org/10.1016/s1097-2765(03)00490-8

Ryzhakov G, Randow F, 2007. SINTBAD, a novel component of innate antiviral immunity, shares a TBK1-binding domain with NAP1 and TANK. EMBO J, 26(13):31803190 .

https://doi.org/10.1038/sj.emboj.7601743

Saitoh T, Yamamoto M, Miyagishi M, et al., 2005. A20 is a negative regulator of IFN regulatory factor 3 signaling. J Immunol, 174(3):1507-1512. https://doi.org/10.4049/jimmunol.174.3.1507

Salio M, Cerundolo V, 2005. Viral immunity: cross-priming with the help of TLR3. Curr Biol, 15(9):R336-R339. https://doi.org/10.1016/j.cub.2005.04.025

Sancho-Shimizu V, de Diego RP, Jouanguy E, et al., 2011. Inborn errors of anti-viral interferon immunity in humans. Curr Opin Virol, 1(6):487-496. https://doi.org/10.1016/j.coviro.2011.10.016

Sander WJ, O'Neill HG, Pohl CH, 2017. Prostaglandin $\mathrm{E}_{2}$ as a modulator of viral infections. Front Physiol, 8:89. https://doi.org/10.3389/fphys.2017.00089

Sarkar SN, Smith HL, Rowe TM, et al., 2003. Double-stranded RNA signaling by Toll-like receptor 3 requires specific tyrosine residues in its cytoplasmic domain. $J$ Biol Chem, 278(7):4393-4396. https://doi.org/10.1074/jbc.C200655200

Sarkar SN, Peters KL, Elco CP, et al., 2004. Novel roles of TLR3 tyrosine phosphorylation and PI3 kinase in doublestranded RNA signaling. Nat Struct Mol Biol, 11(11): 1060-1067. https://doi.org/10.1038/nsmb847

Sasai M, Tatematsu M, Oshiumi H, et al., 2010. Direct binding of TRAF2 and TRAF6 to TICAM-1/TRIF adaptor participates in activation of the Toll-like receptor 3/4 pathway. Mol Immunol, 47(6):1283-1291. https://doi.org/10.1016/j.molimm.2009.12.002

Sato R, Kato A, Chimura T, et al., 2018. Combating herpesvirus encephalitis by potentiating a TLR3-mTORC2 axis. Nat Immunol, 19(10):1071-1082. https://doi.org/10.1038/s41590-018-0203-2

Saxena M, Sabado RL, La Mar M, et al., 2019. Poly-ICLC, a TLR3 agonist, induces transient innate immune responses in patients with treated HIV-infection: a randomized double-blinded placebo controlled trial. Front Immunol,
10:725.

https://doi.org/10.3389/fimmu.2019.00725

Schmid S, Sachs D, Tenoever BR, 2014. Mitogen-activated protein kinase-mediated licensing of interferon regulatory factor $3 / 7$ reinforces the cell response to virus. $J$ Biol Chem, 289(1):299-311. https://doi.org/10.1074/jbc.M113.519934

Schröder M, Bowie AG, 2005. TLR3 in antiviral immunity: key player or bystander? Trends Immunol, 26(9):462468.

https://doi.org/10.1016/j.it.2005.07.002

Sesti-Costa R, Françozo MCS, Silva GK, et al., 2017. TLR3 is required for survival following Coxsackievirus B3 infection by driving $\mathrm{T}$ lymphocyte activation and polarization: the role of dendritic cells. PLoS ONE, 12(10): e0185819. https://doi.org/10.1371/journal.pone.0185819

Shin C, Ito Y, Ichikawa S, et al., 2017. MKRN2 is a novel ubiquitin E3 ligase for the p65 subunit of NF- $\mathrm{BB}$ and negatively regulates inflammatory responses. Sci Rep, 7: 46097. https://doi.org/10.1038/srep46097

Singh D, Qi RS, Jordan JL, et al., 2013. The human antimicrobial peptide LL-37, but not the mouse ortholog, mCRAMP, can stimulate signaling by poly(I: C) through a FPRL1dependent pathway. J Biol Chem, 288(12):8258-8268. https://doi.org/10.1074/jbc.M112.440883

Singh S, Pandey K, Rathore YS, et al., 2014. A communication network within the cytoplasmic domain of Toll-like receptors has remained conserved during evolution. J Biomol Struct Dyn, 32(5):694-700. https://doi.org/10.1080/07391102.2013.787545

Sioud M, 2006. Innate sensing of self and non-self RNAs by Toll-like receptors. Trends Mol Med, 12(4):167-176. https://doi.org/10.1016/j.molmed.2006.02.004

Song GH, Liu BY, Li ZH, et al., 2016. E3 ubiquitin ligase RNF128 promotes innate antiviral immunity through K63-linked ubiquitination of TBK1. Nat Immunol, 17(12): 1342-1351. https://doi.org/10.1038/ni.3588

Song XQ, Liu S, Wang WD, et al., 2020. E3 ubiquitin ligase RNF170 inhibits innate immune responses by targeting and degrading TLR3 in murine cells. Cell Mol Immunol, 17(8):865-874. https://doi.org/10.1038/s41423-019-0236-y

Søreng K, Neufeld TP, Simonsen A, 2018. Membrane trafficking in autophagy. Int Rev Cell Mol Biol, 336:1-92. https://doi.org/10.1016/bs.ircmb.2017.07.001

Sorokin AV, Kim ER, Ovchinnikov LP, 2009. Proteasome system of protein degradation and processing. Biochemistry (Mosc), 74(13):1411-1442. https://doi.org/10.1134/s000629790913001x

Soto JA, Gálvez NMS, Andrade CA, et al., 2020. The role of dendritic cells during infections caused by highly prevalent viruses. Front Immunol, 11:1513. https://doi.org/10.3389/fimmu.2020.01513

Spearman CW, Dusheiko GM, Hellard M, et al., 2019. Hepatitis C. Lancet, 394(10207):1451-1466. 
https://doi.org/10.1016/s0140-6736(19)32320-7

Sun LJ, Wu JX, Du FH, et al., 2013. Cyclic GMP-AMP synthase is a cytosolic DNA sensor that activates the type I interferon pathway. Science, 339(6121):786-791. https://doi.org/10.1126/science.1232458

Tabeta K, Hoebe K, Janssen EM, et al., 2006. The unc93b1 mutation $3 \mathrm{~d}$ disrupts exogenous antigen presentation and signaling via Toll-like receptors 3, 7 and 9. Nat Immunol, 7(2):156-164. https://doi.org/10.1038/ni1297

Takahashi T, Kulkarni NN, Lee EY, et al., 2018. Cathelicidin promotes inflammation by enabling binding of self-RNA to cell surface scavenger receptors. Sci Rep, 8:4032. https://doi.org/10.1038/s41598-018-22409-3

Takeda K, Akira S, 2015. Toll-like receptors. Curr Protoc Immunol, 109:14.12.1-14.12.10. https://doi.org/10.1002/0471142735.im1412s109

Tan YH, Kagan JC, 2019. Innate immune signaling organelles display natural and programmable signaling flexibility. Cell, 177(2):384-398.e11. https://doi.org/10.1016/j.cell.2019.01.039

Tatematsu M, Ishii A, Oshiumi H, et al., 2010. A molecular mechanism for Toll-IL-1 receptor domain-containing adaptor molecule-1-mediated IRF-3 activation. $J$ Biol Chem, 285(26):20128-20136. https://doi.org/10.1074/jbc.M109.099101

Tavora B, Mederer T, Wessel KJ, et al., 2020. Tumoural activation of TLR3-SLIT2 axis in endothelium drives metastasis. Nature, 586(7828):299-304. https://doi.org/10.1038/s41586-020-2774-y

Tjwa ETTL, van Oord GW, Biesta PJ, et al., 2012. Restoration of TLR3-activated myeloid dendritic cell activity leads to improved natural killer cell function in chronic hepatitis B virus infection. J Virol, 86(8):4102-4109. https://doi.org/10.1128/jvi.07000-11

Topping KD, Kelly DG, 2019. Investigation of binding characteristics of immobilized Toll-like receptor 3 with poly(I:C) for potential biosensor application. Anal Biochem, 564-565:133-140. https://doi.org/10.1016/j.ab.2018.05.023

Town T, Jeng D, Alexopoulou L, et al., 2006. Microglia recognize double-stranded RNA via TLR3. J Immunol, 176(6): 3804-3812. https://doi.org/10.4049/jimmunol.176.6.3804

Tseng PH, Matsuzawa A, Zhang WZ, et al., 2010. Different modes of ubiquitination of the adaptor TRAF3 selectively activate the expression of type I interferons and proinflammatory cytokines. Nat Immunol, 11(1):70-75. https://doi.org/10.1038/ni.1819

Uehata T, Takeuchi O, 2020. RNA recognition and immunityinnate immune sensing and its posttranscriptional regulation mechanisms. Cells, 9(7):1701. https://doi.org/10.3390/cells9071701

Unterholzner L, Keating SE, Baran M, et al., 2010. IFI16 is an innate immune sensor for intracellular DNA. Nat Immunol, 11(11):997-1004. https://doi.org/10.1038/ni.1932
Wang K, Liu HL, He YL, et al., 2010. Correlation of TLR1-10 expression in peripheral blood mononuclear cells with chronic hepatitis B and chronic hepatitis B-related liver failure. Hum Immunol, 71(10):950-956. https://doi.org/10.1016/j.humimm.2010.07.013

Wang L, Wen MY, Cao XT, 2019. Nuclear hnRNPA2B1 initiates and amplifies the innate immune response to DNA viruses. Science, 365(6454):eaav0758. https://doi.org/10.1126/science.aav0758

Wang P, Zhao W, Zhao K, et al., 2015. TRIM26 negatively regulates interferon- $\beta$ production and antiviral response through polyubiquitination and degradation of nuclear IRF3. PLoS Pathog, 11(3):e1004726. https://doi.org/10.1371/journal.ppat.1004726

Wang T, Town T, Alexopoulou L, et al., 2004. Toll-like receptor 3 mediates West Nile virus entry into the brain causing lethal encephalitis. Nat Med, 10(12):1366-1373. https://doi.org/10.1038/nm1140

Wang Y, Liu L, Davies DR, et al., 2010. Dimerization of Tolllike receptor 3 (TLR3) is required for ligand binding. J Biol Chem, 285(47):36836-36841. https://doi.org/10.1074/jbc.M110.167973

Wang Y, Yuan SC, Jia X, et al., 2019. Mitochondria-localised ZNFX1 functions as a dsRNA sensor to initiate antiviral responses through MAVs. Nat Cell Biol, 21(11):13461356. https://oi.org/10.1038/s41556-019-0416-0

Wang YY, Tang YW, Teng L, et al., 2006. Association of $\beta$ arrestin and TRAF6 negatively regulates Toll-like receptorinterleukin 1 receptor signaling. Nat Immunol, 7(2):139147. https://doi.org/10.1038/ni1294

Watanabe A, Tatematsu M, Saeki K, et al., 2011. Raftlin is involved in the nucleocapture complex to induce poly(I:C)mediated TLR3 activation. J Biol Chem, 286(12):1070210711 . https://doi.org/10.1074/jbc.M110.185793

Weber C, Müller C, Podszuweit A, et al., 2012. Toll-like receptor (TLR) 3 immune modulation by unformulated small interfering RNA or DNA and the role of CD14 (in TLR-mediated effects). Immunology, 136(1):64-77. https://doi.org/10.1111/j.1365-2567.2012.03559.x

Wilson JR, de Sessions PF, Leon MA, et al., 2008. West Nile virus nonstructural protein 1 inhibits TLR3 signal transduction. $J$ Virol, 82(17):8262-8271. https://doi.org/10.1128/jvi.00226-08

Witczak P, Brzezińska-Błaszczyk E, Agier J, 2020. The response of tissue mast cells to TLR3 ligand poly(I:C) treatment. J Immunol Res, 2020:2140694. https://doi.org/10.1155/2020/2140694

Witherow DS, Garrison TR, Miller WE, et al., 2004. $\beta$-Arrestin inhibits NF- $\kappa \mathrm{B}$ activity by means of its interaction with

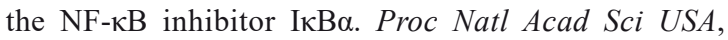
101(23):8603-8607. https://doi.org/10.1073/pnas.0402851101

Wu F, Zhao S, Yu B, et al., 2020. A new coronavirus associated with human respiratory disease in China. Nature, 579(7798): 265-269. 
https://doi.org/10.1038/s41586-020-2008-3

Wu FY, Niu ZM, Zhou B, et al., 2019. PSMB1 negatively regulates the innate antiviral immunity by facilitating degradation of IKK-E. Viruses, 11(2):99. https://doi.org/10.3390/v11020099

Wu HF, Liu HS, Zhao XY, et al., 2020. IKIP negatively regulates NF- $\kappa B$ activation and inflammation through inhibition of IKK $\alpha / \beta$ phosphorylation. J Immunol, 204(2):418427. https://doi.org/10.4049/jimmunol.1900626

Wu JX, Chen ZJ, 2014. Innate immune sensing and signaling of cytosolic nucleic acids. Annu Rev Immunol, 32:461-488. https://doi.org/10.1146/annurev-immunol-032713-120156

Wu X, Lei CQ, Xia T, et al., 2019. Regulation of TRIFmediated innate immune response by K27-linked polyubiquitination and deubiquitination. Nat Commun, 10:4115. https://doi.org/10.1038/s41467-019-12145-1

Xing JJ, Weng LY, Yuan B, et al., 2016. Identification of a role for TRIM29 in the control of innate immunity in the respiratory tract. Nat Immunol, 17(12):1373-1380. https://doi.org/10.1038/ni.3580

Xue QH, Zhou Z, Lei XB, et al., 2012. TRIM38 negatively regulates TLR3-mediated IFN- $\beta$ signaling by targeting TRIF for degradation. PLoS ONE, 7(10):e46825. https://doi.org/10.1371/journal.pone.0046825

Yamashita M, Chattopadhyay S, Fensterl V, et al., 2012. Epidermal growth factor receptor is essential for Toll-like receptor 3 signaling. Sci Signal, 5(233):ra50. https://doi.org/10.1126/scisignal.2002581

Yang Q, Shu HB, 2020. Deciphering the pathways to antiviral innate immunity and inflammation. Adv Immunol, 145:1-36. https://doi.org/10.1016/bs.ai.2019.11.001

Yang Y, Liao B, Wang SY, et al., 2013. E3 ligase WWP2 negatively regulates TLR3-mediated innate immune response by targeting TRIF for ubiquitination and degradation. Proc Natl Acad Sci USA, 110(13):5115-5120. https://doi.org/10.1073/pnas.1220271110

Yang Y, Wang SY, Huang ZF, et al., 2016. The RNA-binding protein Mex3B is a coreceptor of Toll-like receptor 3 in innate antiviral response. Cell Res, 26(3):288-303. https://doi.org/10.1038/cr.2016.16

Ye W, Hu MM, Lei CQ, et al., 2017. TRIM8 negatively regulates TLR3/4-mediated innate immune response by blocking TRIF-TBK1 interaction. J Immunol, 199(5):1856-1864. https://doi.org/10.4049/jimmunol.1601647

Yu YX, Hayward GS, 2010. The ubiquitin E3 ligase RAUL negatively regulates type I interferon through ubiquitination of the transcription factors IRF7 and IRF3. Immunity, 33(6):863-877. https://doi.org/10.1016/j.immuni.2010.11.027

Yuan X, Gajan A, Chu Q, et al., 2018. Developing TRAIL/ TRAIL death receptor-based cancer therapies. Cancer Metastasis Rev, 37(4):733-748. https://doi.org/10.1007/s10555-018-9728-y

Yuk JM, Shin DM, Lee HM, et al., 2011. The orphan nuclear receptor SHP acts as a negative regulator in inflammatory signaling triggered by Toll-like receptors. Nat Immunol, 12(8):742-751. https://doi.org/10.1038/ni.2064

Zang R, Lian H, Zhong X, et al., 2020. ZCCHC3 modulates TLR3-mediated signaling by promoting recruitment of TRIF to TLR3. J Mol Cell Biol, 12(4):251-262. https://doi.org/10.1093/jmcb/mjaa004

Zeng WW, Xu M, Liu SQ, et al., 2009. Key role of Ubc5 and lysine-63 polyubiquitination in viral activation of IRF3. Mol Cell, 36(2):315-325. https://doi.org/10.1016/j.molcel.2009.09.037

Zhang JY, Shen BF, 2011. SHP limits TLR signaling, an inducible transcriptional corepressor. Cell Mol Immunol, 8(6):445-446. https://doi.org/10.1038/cmi.2011.31

Zhang L, Zhao XY, Zhang M, et al., 2014. Ubiquitin-specific protease $2 b$ negatively regulates IFN- $\beta$ production and antiviral activity by targeting TANK-binding kinase 1 . J Immunol, 193(5):2230-2237.

https://doi.org/10.4049/jimmunol.1302634

Zhang LY, Xiang WP, Wang GL, et al., 2016. Interferon $\beta$ (IFN- $\beta$ ) production during the double-stranded RNA (dsRNA) response in hepatocytes involves coordinated and feedforward signaling through Toll-like receptor 3 (TLR3), RNA-dependent protein kinase (PKR), inducible nitric oxide synthase (iNOS), and Src protein. $J$ Biol Chem, 291(29):15093-15107. https://doi.org/10.1074/jbc.M116.717942

Zhang M, Wang LJ, Zhao XY, et al., 2012. TRAF-interacting protein (TRIP) negatively regulates IFN- $\beta$ production and antiviral response by promoting proteasomal degradation of TANK-binding kinase 1. J Exp Med, 209(10): 1703-1711. https://doi.org/10.1084/jem.20120024

Zhang Q, Bastard P, Liu ZY, et al., 2020. Inborn errors of type I IFN immunity in patients with life-threatening COVID-19. Science, 370(6515):eabd4570. https://doi.org/10.1126/science.abd4570

Zhang SY, Jouanguy E, Ugolini S, et al., 2007. TLR3 deficiency in patients with herpes simplex encephalitis. Science, 317(5844):1522-1527. https://doi.org/10.1126/science.1139522

Zhang ZQ, Kim T, Bao MS, et al., 2011. DDX1, DDX21, and DHX36 helicases form a complex with the adaptor molecule TRIF to sense dsRNA in dendritic cells. Immunity, 34(6):866-878. https://doi.org/10.1016/j.immuni.2011.03.027

Zhao BY, Shu C, Gao XS, et al., 2016. Structural basis for concerted recruitment and activation of IRF-3 by innate immune adaptor proteins. Proc Natl Acad Sci USA, 113(24):E3403-E3412. https://doi.org/10.1073/pnas.1603269113

Zhao XB, Zhu HH, Yu J, et al., 2016. c-Cbl-mediated ubiquitination of IRF3 negatively regulates IFN- $\beta$ production and cellular antiviral response. Cell Signal, 28(11):1683-1693. https://doi.org/10.1016/j.cellsig.2016.08.002

Zheng H, Li Q, Chen R, et al., 2013. The dual-specificity phosphatase DUSP14 negatively regulates tumor necrosis factor- and interleukin-1-induced nuclear factor- $\kappa \mathrm{B}$ activation by dephosphorylating the protein kinase TAK1. J Biol 
Chem, 288(2):819-825.

https://doi.org/10.1074/jbc.M112.412643

Zheng QL, Hou J, Zhou Y, et al., 2015. Siglec1 suppresses antiviral innate immune response by inducing TBK1 degradation via the ubiquitin ligase TRIM27. Cell Res, 25(10): 1121-1136. https://doi.org/10.1038/cr.2015.108

Zheng Y, Gao CJ, 2020. Fine-tuning of antiviral innate immunity by ubiquitination. Adv Immunol, 145:95-128. https://doi.org/10.1016/bs.ai.2019.11.004

Zhong X, Feng L, Xu WH, et al., 2020. The zinc-finger protein ZFYVE1 modulates TLR3-mediated signaling by facilitating TLR3 ligand binding. Cell Mol Immunol, 17(7):
741-752.

https://doi.org/10.1038/s41423-019-0265-6

Zhou RY, Zhang Q, Xu PL, 2020. TBK1, a central kinase in innate immune sensing of nucleic acids and beyond. Acta Biochim Biophys Sin, 52(7):757-767. https://doi.org/10.1093/abbs/gmaa051

Zhou Y, Wang X, Sun L, et al., 2016. Toll-like receptor 3activated macrophages confer anti-HCV activity to hepatocytes through exosomes. FASEB J, 30(12):4132-4140. https://doi.org/10.1096/fj.201600696R

Zhu S, Wang G, Lei XQ, et al., 2016. Mex3B: a coreceptor to present dsRNA to TLR3. Cell Res, 26(4):391-392. https://doi.org/10.1038/cr.2016.29 